\title{
TOURISM SECTOR ASSESSMENT, STRATEGY, AND ROAD MAP FOR CAMBODIA, LAO PEOPLE'S DEMOCRATIC REPUBLIC, MYANMAR, AND VIET NAM (2016-2018)
}




\section{TOURISM SECTOR ASSESSMENT, STRATEGY, AND ROAD MAP FOR CAMBODIA, LAO PEOPLE'S DEMOCRATIC REPUBLIC, MYANMAR, AND VIET NAM (2016-2018)}


(C) 2017 Asian Development Bank

6 ADB Avenue, Mandaluyong City, 1550 Metro Manila, Philippines

Tel +632632 4444; Fax +6326362444

www.adb.org

Some rights reserved. Published in 2017.

Printed in the Philippines.

ISBN 978-92-9257-749-0 (Print) 978-92-9257-750-6 (e-ISBN)

Publication Stock No. RPT178657-2

DOI: http://dx.doi.org/10.22617/RPT178657-2

Cataloging-In-Publication Data

Asian Development Bank.

Tourism sector assessment, strategy, and road map for Cambodia, Lao People's Democratic Republic, Myanmar, and Viet Nam (2016-2018).

Mandaluyong City, Philippines: Asian Development Bank, 2017.

1. Tourism. 2. Greater Mekong Subregion. 3. Regional cooperation and integration. I. Asian Development Bank.

The views expressed in this publication are those of the authors and do not necessarily reflect the views and policies of the Asian Development Bank (ADB) or its Board of Governors or the governments they represent.

ADB does not guarantee the accuracy of the data included in this publication and accepts no responsibility for any consequence of their use. The mention of specific companies or products of manufacturers does not imply that they are endorsed or recommended by ADB in preference to others of a similar nature that are not mentioned.

By making any designation of or reference to a particular territory or geographic area, or by using the term "country" in this document, $A D B$ does not intend to make any judgments as to the legal or other status of any territory or area.

This work is available under the Creative Commons Attribution 3.0 IGO license (CC BY 3.0 IGO)

https://creativecommons.org/licenses/by/3.0/igo/. By using the content of this publication, you agree to be bound by the terms of this license.

This CC license does not apply to non-ADB copyright materials in this publication. If the material is attributed to another source, please contact the copyright owner or publisher of that source for permission to reproduce it.

$\mathrm{ADB}$ cannot be held liable for any claims that arise as a result of your use of the material.

Attribution-You should always acknowledge ADB as the source using the following format:

[Author]. [Year of publication]. [Title of the work in italics]. [City of publication]: [Publisher]. (c) ADB. [URL or DOI] [license].

Translations-Any translations you create should carry the following disclaimer:

Originally published by ADB in English under the title [title in italics]. (c) ADB. [URL or DOI] [license]. The quality of the translation and its coherence with the original text is the sole responsibility of the translator. The English original of this work is the only official version.

Adaptations-Any adaptations you create should carry the following disclaimer:

This is an adaptation of an original work titled [title in italics]. (c) ADB. [URL or DOI][license]. The views expressed here are those of the authors and do not necessarily reflect the views and policies of ADB or its Board of Governors or the governments they represent. ADB does not endorse this work or guarantee the accuracy of the data included in this publication and accepts no responsibility for any consequence of their use.

Please contact pubsmarketing@adb.org if you have questions or comments with respect to content, or if you wish to obtain copyright permission for your intended use that does not fall within these terms, or for permission to use the ADB logo.

Notes:

In this publication, "\$” refers to US dollars.

ADB recognizes "Korea" as the Republic of Korea, "Laos" as the Lao People's Democratic Republic, and "Vietnam" as Viet Nam.

Corrigenda to ADB publications may be found at http://www.adb.org/publications/corrigenda 


\section{Contents}

Tables $\quad$ iv

Acknowledgments $\quad \vee$

Abbreviations vi vi

I. Introduction 1

II. Sector Assessment: Context and Strategic Issues 2

A. Global Tourism Trends 2

B. Economic and Social Context 2

C. Tourism in Cambodia, the Lao People's Democratic Republic, Myanmar, and Viet Nam 4

1. Cambodia 6

2. Lao People's Democratic Republic 7

3. Myanmar 7

4. Viet Nam 8

D. Drivers of Tourism Demand 8

1. Improved Physical Connectivity 9

2. Tourist Visa Policies 10

3. Information and Communication Technology 11

4. Rising Affluence of Developing Asia 12

E. Core Tourism Sector Issues, Causes, and Effects 13

1. Enabling Environment 13

2. Human Resources 15

3. Infrastructure 16

4. Protection of Cultural and Natural Assets 18

5. Climate Change 20

6. Market Linkages 21

F. Tourism's Linkages to Other Sector, Thematic, and Regional Cooperation Issues 22

G. Summary of Key Opportunities, Constraints, Development Needs, and Risks 24

III. Sector Strategy 25

A. Government Sector Strategy, Policy, and Plans 25

B. ADB Tourism Support Program and Experience 29

C. Other Development Partner Support 31

D. ADB Experience and Self-Evaluation 32

E. ADB Sector Forward Strategy 34

Appendixes

1 Problem Tree for Tourism in Cambodia, the Lao People's Democratic Republic, Myanmar, and Viet Nam 36

2 Development Partner Assistance: Cambodia, the Lao People's Democratic Republic, Myanmar, and Viet Nam $\quad 37$

3 Strategic Linkages $\quad 40$ 


\section{Tables}

1 Economic and Social Indicators, 2014/2015 3

2 International Visitor Arrivals, 2008-2015 5

3 Tourism's Contribution to Gross Domestic Product and Employment, 2015

4 Characteristics of Key Markets and Destinations, 2015

5 International Inbound Scheduled Air Passenger Traffic, 2012-2014 9

6 Visa Openness, 2013-2015 11

7 Information and Communication Technology-Key Indicators, 2014/2015 12

8 Economic Factors Enabling Outbound Tourism 13

9 Constraints on the Business-Enabling Environment 14

10 Education, Training, and Literacy in the Association of Southeast Asian Nations 15

11 Competitiveness Rankings for Infrastructure, Health, and Hygiene 17

12 Tourism Services Intensity and International Visitor Arrivals 17

13 Natural and Cultural Protected Areas in the Association of Southeast Asian Nations 19

14 Potential Net Income Contributions from Tourism, 202022

15 Tourism Linkages to Other Sectors and Synergies 23

16 Strategic Directions of Government Tourism Sector Strategies 26

17 Tourism Advisory Boards and Industry Associations 27

18 ADB Tourism Support: Cambodia, the Lao People's Democratic Republic, Myanmar, and Viet Nam $\quad 30$

19 Indicative Tourism Support Program 35 


\section{Acknowledgments}

This report was prepared by Steven Schipani, senior portfolio management specialist, Southeast Asia Department (SERD), Asian Development Bank. Guidance and support were provided by James Nugent (director general, SERD), Noriko Ogawa (deputy director general, SERD), Sandra Nicoll (country director, Lao People's Democratic Republic Resident Mission), and Alfredo Perdiguero (principal economist, SERD). Shunsuke Bando (senior country specialist, Lao People's Democratic Republic Resident Mission), Peter Brimble (principal country economist, Myanmar Resident Mission), Jan Hansen (senior country economist, Cambodia Resident Mission), and Yumiko Tamura (principal country specialist, Viet Nam Resident Mission) reviewed the manuscript and provided valuable advice to improve the document.

We also thank the Greater Mekong Subregion Tourism Working Group and the Mekong Tourism Coordinating Office for reviewing and contributing to the report. 


\title{
Abbreviations
}

\author{
ADB Asian Development Bank \\ AFD Agence Française de Développement \\ ASEAN Association of Southeast Asian Nations \\ ASR assessment, strategy, and road map \\ CLMV Cambodia, the Lao People's Democratic Republic, Myanmar, and Viet Nam \\ GDP gross domestic product \\ GMS Greater Mekong Subregion \\ GNI gross national income \\ ICT information and communication technology \\ Lao PDR Lao People's Democratic Republic \\ MRA-TP Mutual Recognition Arrangement on Tourism Professionals \\ PRC People's Republic of China \\ SMEs small and medium-sized enterprises \\ TTCl \\ TVET \\ UNESCO \\ UNWTO \\ Travel and Tourism Competitiveness Index \\ technical and vocational education and training \\ United Nations Educational, Scientific and Cultural Organization \\ United Nations World Tourism Organization
}






\section{Introduction}

1. This sector assessment, strategy, and road map (ASR) documents strategic investment priorities of the Asian Development Bank (ADB) and the governments of Cambodia, the Lao People's Democratic Republic (Lao PDR), Myanmar, and Viet Nam in the tourism sector.' It highlights sector performance, priority development constraints, government plans and strategies, past ADB support and experience, other development partner support, and ADB's future tourism support strategy for Cambodia, the Lao PDR, Myanmar, and Viet Nam (CLMV). The ASR is linked to and informs ADB country partnership strategies for CLMV. It will be updated as strategic developments and program changes are needed and will help to provide sector background information for investment and technical assistance operations.

2. The ASR is consistent with the midterm review of ADB Strategy 2020 and ADB's sharpened focus on poverty reduction and inclusive growth, the environment and climate change, regional cooperation and integration, and infrastructure development, with due consideration given to private sector development and knowledge solutions to foster innovation. ${ }^{2}$ Preparation of this document entailed a comprehensive desk review of tourism trends and an analysis of the role and importance of tourism to the CLMV economies. Meaningful consultations were held with government, the private sector, civil society organizations, and other development partners to validate the report's findings and recommendations, which are closely aligned with the Action Program on CLMV Tourism Cooperation 2016-2018, the Greater Mekong Subregion (GMS) Tourism Sector Strategy 2016-2025, and Association of Southeast Asian Nations (ASEAN) Tourism Strategic Plan 2016-2025. The ASR was peer reviewed by CLMV national tourism organizations, ADB staff, and members of private industry associations with in-depth knowledge of tourism in Asia and the Pacific.

\footnotetext{
1 The tourism sector is defined as the cluster of production units in different industries that provide consumption goods and services demanded by visitors. Tourism entails the movement of people to countries or places outside their usual environment for personal or business purposes. These people are called visitors (or tourists), who may be either overnight or same-day visitors, residents or nonresidents. Tourism involves their activities, some of which imply tourism expenditure (United Nations World Tourism Organization).

2 ADB. 2014. Midterm Review of Strategy 2020: Meeting the Challenges of a Transforming Asia and Pacific. Manila. Inclusive growth is defined as economic growth that is broad-based across sectors and creates good jobs that benefit a large proportion of the population. It reduces the vulnerability of the poor and expands access to social services and productive assets for all.
} 


\section{Sector Assessment: Context and Strategic Issues}

\section{A. Global Tourism Trends}

3. According to the United Nations World Tourism Organization (UNWTO), international visitor arrivals reached 1.18 billion in 2015 , a 4.4\% increase compared to 2014. Corresponding tourism expenditure generated in destination countries from the purchase of accommodation, food, local transport, shopping, entertainment, and other tourism-related goods and services by international visitors totaled $\$ 1.23$ trillion. The wider travel and tourism industry generated $\$ 7.2$ trillion in $2015-$ about $10 \%$ of global output-and supported 284 million jobs. ${ }^{3}$ Tourists from emerging economies represented a $45 \%$ share of international visitor arrivals in 2015, up from $38 \%$ in 2000 . About $80 \%$ of global visitor arrivals are intraregional. Nearly half of international travel is for leisure, followed by visiting friends and relatives, pilgrimage, and business. The People's Republic of China (PRC) leads the world in annual international tourism expenditure ( $\$ 229$ billion), followed by the United States ( $\$ 120$ billion) and Germany ( $\$ 76$ billion). The long-term outlook for global tourism growth is bright, with UNWTO forecasting international visitor arrivals will rise an average 3.3\% per year and reach 1.8 billion in 2030. Visitor arrivals in emerging destinations are expected to increase by $4.4 \%$ per year, or nearly twice the rate of increase in advanced economies. ${ }^{4}$

4. Asia and the Pacific received 279 million international visitors in 2015, an increase of $5.4 \%$ compared to 2014. UNWTO's long-term forecasts suggest Asia and the Pacific will remain the world's fastest-growing region through 2030, when international visitor arrivals are expected to reach 535 million and represent $30 \%$ of the global market share. Over the medium term, according to World Travel and Tourism Council estimates, Asia and the Pacific travel and tourism will generate $\$ 3.7$ trillion and sustain 197 million jobs by 2024. Within Asia and the Pacific, the 10 Southeast Asian countries that comprise ASEAN are among the world's fastest-growing tourist destinations. ASEAN received 108 million international visitors in 2015, up more than $45 \%$ from just 6 years earlier. International visitor arrivals in ASEAN are expected to continue increasing by $5.1 \%$ per year and reach 187 million in 2030.

\section{B. Economic and Social Context}

5. Cambodia, the Lao PDR, Myanmar, and Viet Nam (CLMV) are strategically located between the Southeast Asian archipelago, India, and the PRC. They are rapidly developing members of ASEAN, covering a total land area of 1.4 million square kilometers with a combined population of approximately 165 million people. The majority live in rural areas and are engaged in agriculture. However, migration to urban areas-primarily by young adults seeking better economic

\footnotetext{
3 World Travel \& Tourism Council. 2016. Travel \& Tourism Economic Impact 2016 World. London.

4 United Nations World Tourism Organization. 2015. UNWTO World Tourism Barometer, January. Madrid.
} 
opportunities-is increasing. Impressive economic performance is driven by the expansion of industry and services, including tourism, although a considerable gap remains between CLMV and their wealthier neighbors in ASEAN (Table 1).

\section{Table 1: Economic and Social Indicators, 2014/2015}

\begin{tabular}{|l|c|c|c|c|c|}
\hline & $\begin{array}{c}\text { Pross National } \\
\text { Income } \\
\text { Per Capita } \\
\text { (million) }\end{array}$ & $\begin{array}{c}\text { (\$) } \\
\text { Gross Domestic } \\
\text { Product Growth } \\
(\%)\end{array}$ & $\begin{array}{c}\text { Poverty } \\
\text { Rate } \\
(\%)\end{array}$ & $\begin{array}{c}\text { 2015 United Nations } \\
\text { Development Programme } \\
\text { Human Development } \\
\text { Index Ranking }\end{array}$ \\
\hline Cambodia & 15.4 & 1,020 & 7.0 & 13.5 & 143 \\
\hline Lao PDR & 6.5 & 1,660 & 6.7 & 23.2 & 141 \\
\hline Myanmar & 52.1 & 1,270 & 7.2 & 25.6 & 148 \\
\hline Viet Nam & 91.7 & 1,890 & 6.7 & 8.4 & 116 \\
\hline Brunei Darussalam & 0.4 & 37,320 & -1.1 & --- & 31 \\
\hline Indonesia & 255.5 & 3,630 & 4.8 & 11.2 & 110 \\
\hline Malaysia & 31.0 & 11,120 & 5.0 & 0.6 & 62 \\
\hline Philippines & 101.6 & 3,500 & 5.8 & 25.2 & 115 \\
\hline Singapore & 5.5 & 55,150 & 2.0 & --- & 11 \\
\hline Thailand & 67.2 & 5,780 & 2.8 & 10.9 & 93 \\
\hline
\end{tabular}

--- = data not available, Lao PDR = Lao People's Democratic Republic.

Sources: ADB. Basic Statistics 2016. Manila; ADB. Asian Development Outlook 2016. Manila; United Nations Development Programme. Human Development Report 2015. New York.

6. Recent assessments show that the percentage of the population below the poverty line of $\$ 1.90$ per day (purchasing power parity) is lowest in Viet Nam (8.4\%), followed by Cambodia (13.5\%) and the Lao PDR (23.2\%). ${ }^{5}$ The majority of poverty is rural, but pockets of urban poverty are also found. Households headed by women are more likely to be poor than households headed by men, and poverty rates tend to be much higher among ethnic minorities. After making good progress in reducing income poverty in recent years, many families remain highly vulnerable to shocks such as price increases for essential goods and natural disasters. Vulnerability is exacerbated by weak national social protection systems and low access to affordable finance.

7. Gross domestic product (GDP) growth in 2015 was highest in Myanmar (7.2\%), followed by Cambodia (7\%), the Lao PDR (6.7\%), and Viet Nam (6.7\%). Per capita gross national income (GNI) is highest in Viet Nam $(\$ 1,890)$ and lowest in Cambodia $(\$ 1,020)$. Although CLMV are all transitioning to lower middle-income status, their GNI significantly lags behind the levels reached in Brunei Darussalam, Indonesia, Malaysia, the Philippines, Thailand, and Singapore (ASEAN-6), where it ranges from $\$ 3,500$ to more than $\$ 55,000$. Cambodia is expecting its GDP to increase by $7 \%$ in 2016 and 7.1\% in 2017, while growth in the Lao PDR is forecast to moderate at $6.8 \%$ in 2016 and then edge up to 7\% in 2017. Myanmar is expecting annual GDP growth will accelerate to about 8.4\% in 2016-2017. GDP growth in Viet Nam is forecast to increase by 6.7\% in 2016 and $6.5 \%$ in 2017. Over the medium term, sustained economic growth will be increasingly driven by integration into regional value chains, infrastructure investment, natural resource exploitation, and continued diversification into light manufacturing and services. Lower oil prices are expected to boost growth and increase household disposable income, generating positive spillovers for domestic and intraregional travel and tourism.

ADB. 2016. Basic Statistics 2016. Manila. 
8. Against this backdrop of rapid economic growth, CLMV still rank low on the Human Development Index, a composite index measuring average achievement in three basic dimensions of human development: a long and healthy life, knowledge, and a decent standard of living. Myanmar is ranked 148 among 188 countries assessed, the Lao PDR is ranked 141, Cambodia is ranked 143, and Viet $\mathrm{Nam}$ is ranked $116 .{ }^{6}$ Downbeat perceptions of well-being substantiate the rankings. For example, only $49 \%$ of Cambodia's population is satisfied with their standard of living, and in Myanmar the percentage is $45 \%$. Satisfaction with life circumstances is also low, as measured by the Life Satisfaction Index, with the average score of 5.5 (out of 10) for Viet Nam, 4.9 for the Lao PDR, 4.4 for Myanmar, and 3.9 for Cambodia. This may be partly attributed to rising inequality and the growing gap in prosperity between rural and urban areas. From 2004 to 2013, inequality widened most in the Lao PDR, where the Gini coefficient-a common measure of inequality-worsened, from 32.5 to 36.7 .

9. To address inequality and vulnerability, government, development partners, business, and civil society should focus more resources on enabling small and medium-sized enterprises (SMEs) development; improve health, education, and other social services; and, where appropriate, develop targeted social protection schemes such as conditional cash transfers to the poor. Improving transport and communications networks that link urban and rural areas is essential, to strengthen market linkages and diversify economic growth. More efficient tax generation, collection, and administration is also needed to help ease fiscal constraints that impede public investment in infrastructure and social services. ${ }^{8}$ Tourism growth supports CLMV's efforts to tackle these issues by stimulating SMEs investment in services, manufacturing, and agriculture. It creates good jobs suitable for both unskilled and skilled workers, particularly women and youths. If well managed, tourism also generates significant tax revenue and stimulates merchandise exports by reducing variable trade costs and mitigating market failures related to information deficiencies. Recent studies suggest a $1 \%$ increase in tourist arrivals to an exporting country increases that country's exports to the tourist's home country by $9 \%{ }^{9}$

\section{Tourism in Cambodia, the Lao People's Democratic Republic, Myanmar, and Viet Nam}

10. $\quad C L M V$ are richly endowed with diverse natural and cultural tourism assets. After emerging from decades of conflict, they all prioritize tourism in their national socioeconomic development plans because of its potential to create jobs, generate foreign exchange receipts, accelerate regional economic integration and, importantly, promote friendship and goodwill among nations. Government ministries responsible for tourism (national tourism organizations) are the Ministry of Tourism, Cambodia; the Ministry of Hotels and Tourism, Myanmar; the Ministry of Information, Culture and Tourism, Lao PDR; and the Ministry of Culture, Sports and Tourism, Viet Nam.

11. As a result of supportive government policies, the average annual growth rate of international visitor arrivals to CLMV is 15\%, approximately twice the rate in ASEAN-6 (Table 2). CLMV attained an all-time high of 22.08 million international visitors in 2015. Domestic tourism is also substantial, led by Viet Nam, with more than 30 million annual domestic trips, followed by Cambodia ( 8.5 million), Myanmar (2.2 million), and the Lao PDR (2.1 million). Although recent growth has been impressive, CLMV receive only $20 \%$ of ASEAN's total international visitor arrivals.

\footnotetext{
6 United Nations Development Programme. 2015. Human Development Report 2015. New York.

7 World Bank. 2014. World Development Indicators Database. Washington, DC.

8 ADB. 2012. Asian Development Outlook 2012. Manila.

9 M. Santana-Gallego, F. Ledesma-Rodríguez, and J. Pérez-Rodríguez. 2016. International Trade and Tourism Flows: An Extension of the Gravity Model. Elsevier.
} 
Table 2: International Visitor Arrivals, 2008-2015 ('000)

\begin{tabular}{|c|c|c|c|c|c|c|c|}
\hline & 2008 & 2010 & 2012 & 2014 & 2015 & $\begin{array}{c}\text { Average Annual } \\
\text { Growth Rate } \\
(\%)\end{array}$ & $\begin{array}{c}\text { ASEAN } \\
\text { Share } \\
(\%)\end{array}$ \\
\hline Cambodia & 2,125 & 2,508 & 3,584 & 4,503 & 4,775 & 12.3 & 4.4 \\
\hline Lao PDR & 1,736 & 2,513 & 3,330 & 4,159 & 4,684 & 15.2 & 4.3 \\
\hline Myanmar & 193 & 792 & 1,058 & 3,081 & 4,681 & 57.7 & 4.3 \\
\hline Viet Nam & 4,207 & 5,050 & 6,848 & 7,874 & 7,944 & 9.5 & 7.3 \\
\hline Subtotal & 8,261 & 10,863 & 14,820 & 19,617 & 22,084 & 15.1 & 20.3 \\
\hline Brunei Darussalama & 226 & 214 & 209 & 201 & 218 & -0.5 & 0.2 \\
\hline Indonesia & 5,506 & 7,003 & 8,045 & 9,435 & 10,407 & 9.5 & 9.6 \\
\hline Malaysia & 20,236 & 24,577 & 25,033 & 27,437 & 25,721 & 3.5 & 23.6 \\
\hline Philippines & 3,092 & 3,521 & 4,273 & 4,833 & 5,361 & 8.2 & 4.9 \\
\hline Singapore & 10,288 & 11,639 & 14,491 & 15,095 & 15,231 & 5.8 & 14.0 \\
\hline Thailand & 14,464 & 15,936 & 22,354 & 24,780 & 29,881 & 10.9 & 27.4 \\
\hline Subtotal (ASEAN-6) & 53,812 & 62,890 & 74,405 & 81,781 & 86,819 & 7.1 & 79.7 \\
\hline Total (ASEAN) & 62,073 & 73,753 & 89,225 & 101,398 & 108,903 & 8.4 & 100 \\
\hline
\end{tabular}

--- = data not available, ASEAN = Association of Southeast Asian Nations, Lao PDR = Lao People's Democratic Republic.

a International arrivals by air only for Brunei Darussalam.

Sources: ASEAN Secretariat and national tourism organization estimates.

12. In 2015, international tourism generated $\$ 15$ billion and supported about 4.6 million jobs in CLMV (Table 3). This represents a 49\% increase in tourism employment compared to 2013. Across the four countries, about $\$ 3,500$ in tourism expenditure sustains one job. The direct contribution of travel and tourism to GDP is highest in Cambodia (13.5\%), followed by Viet Nam (6.6\%), the Lao PDR (4.6\%), and Myanmar (2.6\%). Investment in tourism-characteristic subsectors such as hotels, air and land transport services, and leisure and recreation services that deal directly with tourists totaled $\$ 4.75$ billion in 2014 and rose to $\$ 6.1$ billion in 2015. Average expenditure per visitor, inclusive, is lowest in the Lao PDR (\$155) and highest in Viet Nam $(\$ 1,204) .{ }^{10}$ Average expenditure per visitor in Asia and the Pacific is $\$ 1,500 .{ }^{11}$

13. At least half of tourism workers in CLMV are women, but gender profile by job type varies considerably. Women tend to be employed in lower-skilled jobs paying lower wages, while men hold more managerial positions in government and private tourism enterprises. This situation is consistent with global benchmarks, which indicate that women comprise $33 \%$ of senior management in hospitality professions and $27 \%$ of leadership positions in food and beverage services. ${ }^{12}$ Many poor and lowerincome women enter the tourism sector with small personal investments. Most would benefit from better access to affordable credit and vocational training; this is particularly true for ethnic women and when the household head is a woman.

\footnotetext{
10 Overall average expenditure per visitor figures in Table 3 includes overnight visitor and day-tripper spending.

11 United Nations World Tourism Organization. 2016. UNWTO World Tourism Barometer, May. Madrid.

12 Grant Thornton. 2015. Women in Business: The Path to Leadership. London.
} 


\section{Table 3: Tourism's Contribution to Gross Domestic Product and Employment, 2015}

\begin{tabular}{|l|c|c|c|c|}
\hline & Cambodia & Lao PDR & Myanmar & Viet Nam \\
\hline International visitor expenditure (\$ billion) & 3.01 & 0.73 & 2.12 & 9.56 \\
\hline Direct contribution to gross domestic product (\%) & 13.5 & 4.6 & 2.6 & 6.6 \\
\hline Tourism investment (\$ billion) & 0.4 & 0.4 & 0.1 & 5.2 \\
\hline Tourism employment (direct) & $1,034,700$ & 122,900 & 661,000 & $2,783,800$ \\
\hline Women's share of employment (\%) & 54 & 50 & --- & 70 \\
\hline Average expenditure per visitor (\$) & 631 & 155 & 453 & 1,204 \\
\hline
\end{tabular}

--- = data not available, Lao PDR = Lao People's Democratic Republic.

Sources: National tourism organizations; ADB. 2009. Gender-Related Impacts of the Global Economic Slowdown in the Greater Mekong Subregion: Emerging Trends and Issues. Manila; World Travel \& Tourism Council.

14. An overview of CLMV's key markets, travel and spending patterns, tourism services, and popular destinations is presented below.

\section{Cambodia}

15. International visitor arrivals in Cambodia rose to 4.78 million in 2015, a $6 \%$ increase compared to 2014. Viet Nam is the largest source market (20.7\%), followed by the PRC (14.5\%) and the Lao PDR (8.5\%). Other significant medium- and long-haul source markets are the Republic of Korea, Japan, France, and the United States. Thailand is the fastest-growing market from a substantial base, increasing by $25 \%$ in $2015 .{ }^{13}$ International tourists that visit as part of a package tour stay in Cambodia for an average 4.6 days, while independent travelers stay for 7 days. Average daily spending across all international overnight markets is about $\$ 120$ per day. Airports in Phnom Penh and Siem Reap together receive $52 \%$ of total international visitor arrivals; $45 \%$ enter the country through overland borders and $3 \%$ enter by water. The busiest land border checkpoints are Poipet (Cambodia-Thailand) and Bavet (Cambodia-Viet Nam), with each processing about 20\% of international visitor arrivals. Casino tourism at these borders is a key attraction. ${ }^{14}$ Siem Reap and Phnom Penh are the most popular destinations, but tourism in the coastal zone is growing. Leisure is the main purpose of visits, followed by business and visiting friends and relatives. ${ }^{15}$

16. During 2004-2013, the number of hotels and guesthouses more than doubled, to 2,007, with 31,223 bedrooms. Accommodation choices range from small family-owned enterprises to five-star internationally branded properties. Cambodia has 585 travel agencies and tour operators employing 3,230 licensed guides, $89 \%$ of whom are based in Siem Reap. The international airports in Phnom Penh and Siem Reap are served by 23 airlines and receive about 28,000 flights per year, with 4.2 million scheduled inbound seats. Cambodia allows tourist visa on arrival for 179 countries and tourist visa exemption for citizens of all ASEAN member states.

13 A substantial base is defined as at least 25,000 annual arrivals from the source market considered.

14 H. Ashton and L. Korpi. 2009. Asia Awakens: The Growth of Casino Tourism. London.

15 Ministry of Tourism, Cambodia. 2013. Tourism Statistics Annual Report 2013. Phnom Penh. 


\section{Lao People's Democratic Republic}

17. International visitor arrivals to the Lao PDR totaled 4.68 million in 2015 , a $13 \%$ increase compared to 2014 . Thailand is the largest source market and accounts for $49.6 \%$ of international arrivals, followed by Viet Nam (25.4\%) and the PRC (10.9\%). The main medium- and long-haul markets are the Republic of Korea, France, and the United States. The fastest-growing market, from a substantial base, is the Republic of Korea. Long-haul overnight international visitors stay an average of 7.5 days and spend $\$ 77$ per day, while intraregional visitors entering with a passport stay an average of 3 days and spend $\$ 43$ per day. About 33\% of all reported visitor arrivals are lower-spending daytrippers who mainly enter at Vientiane Capital, Savannakhet, and Luang Namtha. The main purpose of visit is leisure, religious pilgrimage, or business. There is also an active gaming industry, with border casinos in Savannakhet and Bokeo provinces. The most popular destinations are Vientiane Capital, Savannakhet, Vientiane Province, and Luang Prabang. Less than 1\% of international visitors use inbound tour operators, but half combine their visit to the Lao PDR with a visit to Thailand. ${ }^{16}$

18. The Lao PDR has 2,449 guesthouses and hotels, with 48,386 bedrooms, of which less than $10 \%$ are five-star rated. After recently reducing barriers to international investment in tour services, the number of registered operators more than doubled to 336 between 2009 and 2015; however, the number of active licensed tour guides (604) is insufficient to meet demand. International airports in Luang Prabang, Pakse, Savannakhet, and Vientiane are served by 9,900 flights per year, with 1.16 million scheduled inbound seats. The Lao PDR allows tourist visa on arrival for 180 countries and tourist visa exemption for citizens of all ASEAN member states.

\section{Myanmar}

19. Myanmar received 4.68 million international visitors in 2015 -a 51.9\% increase compared to 2014-including 1.3 million overnight visitors who arrived by air and 3.38 million day-trippers who entered by land. The main source markets are Thailand, comprising $15.7 \%$ of international overnight visitors, the PRC (11.4\%), and Japan (6.9\%). Other important medium- and long-haul markets are the Republic of Korea and the United States. ${ }^{17}$ Average length of stay for international overnight visitors is 9 days and average spending is $\$ 171$ per day. Excluding accommodations, overnight visitors spend the most on activities and tours, shopping, and meals. The main purpose of visit is leisure, business, or visiting friends and relatives. Myanmar's key tourism assets are its historic heritage in Yangon and other cities, unspoiled sea beaches, and diverse cultural and natural attractions. Popular destinations include Yangon, Bagan, Mandalay, and Inle Lake.

20. Myanmar has 1,279 hotels and guesthouses, with 49,946 bedrooms. There are 48 properties in the development pipeline, financed by foreign direct investment, which soon will add 9,132 bedrooms. Since opening its economy in 2011, Myanmar has fully adopted the ASEAN Framework Agreement on Visa Exemption, introduced tourist visa on arrival services for 26 countries, and permits electronic tourist visas for more than 100 countries. ${ }^{18}$ International inbound flights have grown from 4,200 in 2011 to 14,700 in 2014, with 2.5 million scheduled inbound seats. Efforts to improve roads and bridges in the Greater Mekong Subregion (GMS) East-West and North-South economic corridors, together with modernization of immigration facilities, will help accelerate regional integration and is expected to boost tourism flows across land borders with the Lao PDR, the PRC, and Thailand. ${ }^{19}$ Myanmar has 1,946 licensed tour companies and 5,630 licensed tour guides.

\footnotetext{
16 Ministry of Information, Culture, and Tourism, Lao PDR. 2015. Tourism Statistics Annual Report 2015. Vientiane.

17 Ministry of Hotels and Tourism, Myanmar. 2015. Myanmar Tourism Statistics 2015. Nay Pyi Taw.

18 The electronic visa system was launched in September 2014.

19 GMS includes the Kingdom of Cambodia, Guangxi Zhuang Autonomous Region and Yunnan Province of the People's Republic of China, the Lao PDR, the Republic of the Union of Myanmar, the Kingdom of Thailand, and the Socialist Republic of Viet Nam.
} 


\section{Viet Nam}

21. International visitor arrivals to Viet Nam reached 7.94 million in 2015 , a $0.9 \%$ increase compared to 2014. The main source markets are the PRC (22.4\%), the Republic of Korea (14\%), Japan (8.5\%), the United States (6.2\%) and Taipei,China (5.5\%). Malaysia (4.4\%), the Russian Federation (4.3\%), Australia (3.8\%), and Singapore (3\%) are also important medium- and long-haul markets. ${ }^{20}$ Average length of stay for international overnight visitors is about 7 days and average daily spending is $\$ 105$. International visitors on package tours comprise $48 \%$ of all international arrivals and stay for 10.8 days on average, while independent travelers' average length of stay is 12 days. The most popular destinations are Ha Noi, Ho Chi Minh City, Ha Long Bay (Quang Ninh Province), Thua Thien Hue, Hoi An (Quang Nam Province), and Da Nang. The main purpose of travel is leisure, business, or visiting friends and relatives. Culture and nature are the main attractions. Vietnamese cuisine is also an important tourism asset.

22. Viet Nam has more than 12,000 accommodation establishments, with 235,000 bedrooms, 10,756 of which are five-star rated. From 2001 to 2010, the accommodation subsector expanded by $15.8 \%$ per year and cumulative investment totaled $\$ 11$ billion for 247 projects. There are approximately 1,500 international tour operators and more than 10,000 agencies that cater to domestic tourists, with more than 15,000 licensed tour guides. The international airports in $\mathrm{Ha} \mathrm{Noi,} \mathrm{Ho} \mathrm{Chi} \mathrm{Minh} \mathrm{City,}$ Hue, Can Tho, and Da Nang receive about 57,000 flights per year, with 11.4 million scheduled inbound seats. Viet Nam offers prearranged visa on arrival for 182 countries and visa exemption for all ASEAN member states.

\section{Drivers of Tourism Demand}

23. Apart from key attractions (Table 4), tourism growth in CLMV is driven mainly by improved physical connectivity with regional and global markets, facilitative tourist visa policies, rapid advances in information and communication technology (ICT), and the rising affluence of developing Asia.

Table 4: Characteristics of Key Markets and Destinations, 2015

\begin{tabular}{|c|c|c|c|c|}
\hline & Cambodia & Lao PDR & Myanmar & Viet Nam \\
\hline $\begin{array}{l}\text { Top three markets } \\
\text { and share of arrivals } \\
\text { (\%) }\end{array}$ & $\begin{array}{l}\text { Viet Nam (20.7) } \\
\text { PRC (14.5) } \\
\text { ROK (8.3) }\end{array}$ & $\begin{array}{l}\text { Thailand (49.6) } \\
\text { Viet Nam (25.4) } \\
\text { PRC (10.9) }\end{array}$ & $\begin{array}{l}\text { Thailand (15.7) } \\
\text { PRC (11.3) } \\
\text { Japan (6.9) }\end{array}$ & $\begin{array}{l}\text { PRC (22.4) } \\
\text { ROK (14.0) } \\
\text { Japan (8.5) }\end{array}$ \\
\hline Arrivals by air (\%) & 50.50 & 11.11 & 25.79 & 78.94 \\
\hline Arrivals by land (\%) & 47.40 & 88.88 & 73.66 & 18.92 \\
\hline Arrivals by water (\%) & 2.10 & 0.00 & 0.55 & 2.14 \\
\hline $\begin{array}{l}\text { Main tourist } \\
\text { destinations }\end{array}$ & $\begin{array}{l}\text { Siem Reap- } \\
\text { Angkor Wat } \\
\text { Phnom Penh }\end{array}$ & $\begin{array}{l}\text { Vientiane Capital } \\
\text { Savannakhet } \\
\text { Luang Prabang } \\
\text { Champassak }\end{array}$ & $\begin{array}{l}\text { Yangon } \\
\text { Bagan } \\
\text { Inle Lake } \\
\text { Mandalay }\end{array}$ & $\begin{array}{l}\text { Ha Noi } \\
\text { Ho Chi Minh City } \\
\text { Ha Long Bay } \\
\text { Hue-Hoi An and Da Nang }\end{array}$ \\
\hline Key attractions & $\begin{array}{l}\text { History, culture, } \\
\text { nature, and } \\
\text { gaming }\end{array}$ & $\begin{array}{l}\text { Culture, history, } \\
\text { nature, shopping, } \\
\text { and gaming }\end{array}$ & $\begin{array}{l}\text { Culture, history, } \\
\text { nature, and } \\
\text { landscapes }\end{array}$ & $\begin{array}{l}\text { History, culture, nature, } \\
\text { beaches, shopping, and } \\
\text { landscapes }\end{array}$ \\
\hline
\end{tabular}

Lao PDR = Lao People's Democratic Republic, PRC = People's Republic of China, ROK = Republic of Korea. Source: National tourism organization estimates.

20 Viet Nam National Administration of Tourism. 2014. Viet Nam Tourism Statistics 2014. Ha Noi. 


\section{Improved Physical Connectivity}

24. Airport modernization and the rapid increase in scheduled air services is strongly influencing CLMV's tourism growth. Significant ASEAN-wide investments in infrastructure and aircraft, backed by steady progress toward establishment of a single aviation market under the ASEAN multilateral agreement on air services and ASEAN multilateral agreement for the full liberalization of passenger air services (the ASEAN "open skies agreement") now make it possible to fly direct between most capital cities in ASEAN and a growing list of secondary cities. This is facilitating a sharp rise in intra-ASEAN air passenger traffic, particularly using low-cost carriers, and streamlined global access to CLMV through large international airports in Bangkok, Singapore, and Kuala Lumpur. For instance, international scheduled inbound flights to CLMV increased by $24.3 \%$, to 111,200 , from 2012 to 2014, and inbound seats increased by 24\%, to 19.5 million, over the same period (Table 5). This upward trend is expected to continue over the long term, with Boeing forecasting the combined fleet size of Southeast Asian airlines will increase from 1,190 airplanes in 2013 to 3,770 airplanes in $2033,73 \%$ of which will be single-aisle jets to serve regional leisure and business travelers. ${ }^{21}$ CLMV also will benefit from the expansion of handling capacity at Bangkok's gateway Suvarnabhumi International Airport, to 80 million passengers per year by 2020, and renovation of Bangkok's Don Mueang International Airport-a regional hub for low-cost carriers - that will bring its annual capacity up to 30 million in 2016.

Table 5: International Inbound Scheduled Air Passenger Traffic, 2012-2014

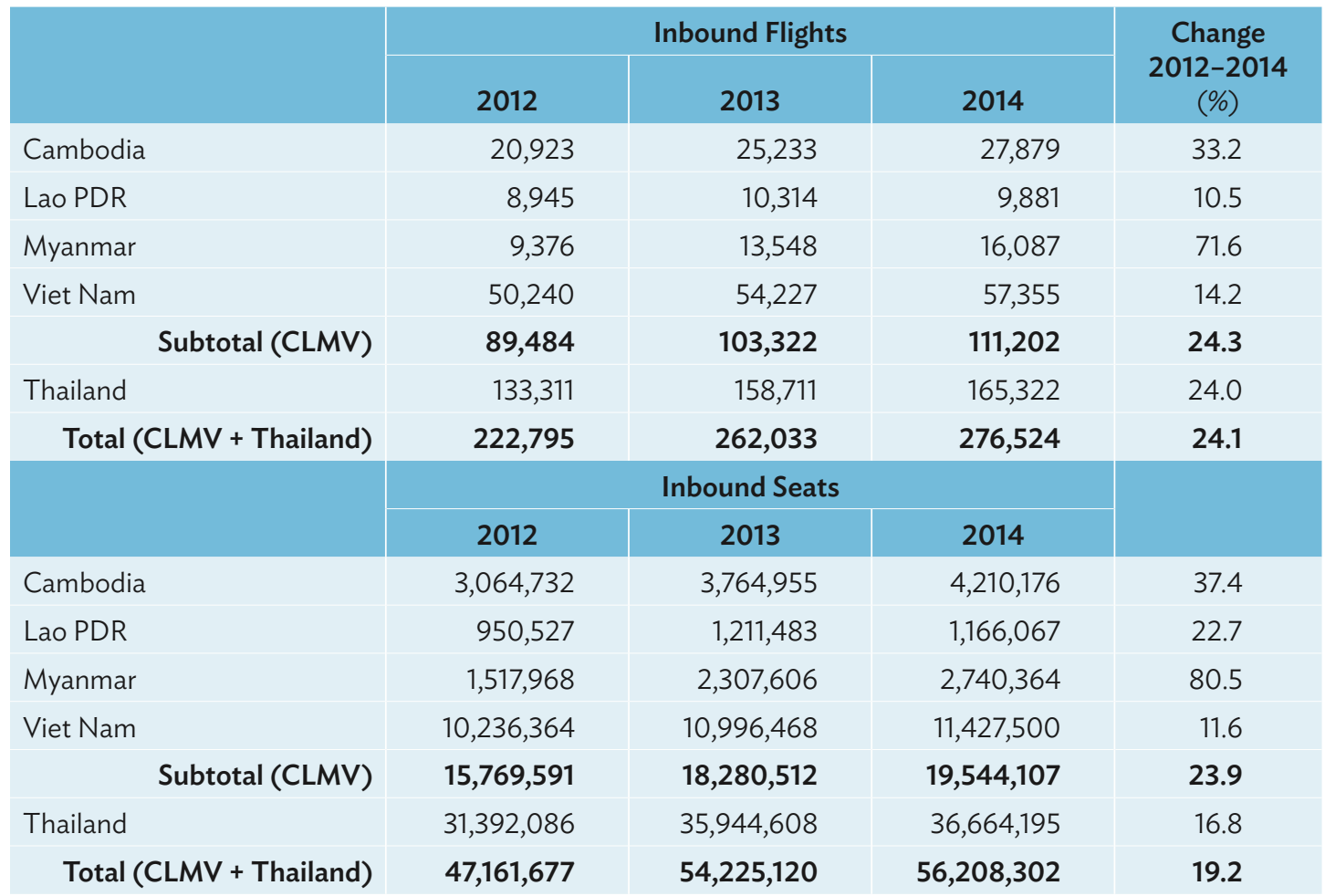

CLMV = Cambodia, the Lao People's Democratic Republic, Myanmar, and Viet Nam; Lao PDR = Lao People's Democratic Republic.

Source: SRS Analyzer via Pacific Asia Travel Association mPower.

${ }^{21}$ Boeing. 2015. Current Market Outlook 2014-2033. Seattle. 
25. Increasingly convenient surface travel in mainland Southeast Asia and between southern PRC and the Lao PDR, Myanmar, and Viet Nam is another factor fueling intraregional leisure travel. Travel times by road have decreased significantly following construction of the transnational highways that link CLMV to large outbound-generating markets in the PRC and Thailand. Intraregional surface travel also is made easier by newly introduced cross-border transport agreements. These enable investment in international tourist coach services and the movement of more personal vehicles across borders. In 2010, for example, 97,000 personal vehicles and 54,000 buses used the second Lao PDR-Thailand Mekong Friendship Bridge, which connects Mukdahan, Thailand, to Savannakhet, Lao PDR. This is a 560\% increase in personal vehicles and a $412 \%$ increase in bus traffic compared to 2007.22 Meanwhile, international visitor arrivals to the Lao PDR via the first Lao PDR-Thailand Mekong Friendship Bridge, connecting Nong Khai, Thailand, to Vientiane, Lao PDR, reached 1.2 million in 2015. Boten, situated at the Lao PDR's northern border with the PRC, in the GMS North-South Economic Corridor, received 373,026 international visitor arrivals in 2015 , an increase of $82.9 \%$ compared to 2013 . The ease of visiting more than one country by land, air, or a combination of both is an attractive value proposition that CLMV offers time-constrained consumers.

26. Leisure cruising on the Mekong and Irrawaddy Rivers is also growing. There are scheduled cruises between Phnom Penh, Cambodia, and several towns in Viet Nam's Mekong Delta; Jinghong, PRC, and Chiang Saen, Thailand; Chiang Kong, Thailand, and Luang Prabang, Lao PDR; and YangonMandalay-Bagan, within Myanmar. Luxury cruising on the lower Mekong River was boosted by enactment of the updated Agreement Between the Socialist Republic of Viet Nam and the Royal Government of Cambodia on Waterway Transportation, which sets out the framework facilitating waterborne transportation of passengers and cargo between the two countries, and transit of passengers to and from third countries. Since the agreement came into force in 2009, the 62-meter Aqua Mekong (40-passenger capacity), 92-meter AmaDara (142-passenger capacity), 92-meter AmaLotus (142-passenger capacity), and several smaller ships have been launched. As a result, about 75,000 international tourists entered Cambodia by water in 2013, mostly at the Kaoam Samnor border gate on the Mekong River. International arrivals to Viet Nam by water numbered 47,583 in 2014, up just 3\% compared to 2008, while Myanmar welcomed 18 oceangoing cruise ships, with 18,611 passengers, in the same year-a threefold increase over 2013.

\section{Tourist Visa Policies}

27. According to the UNWTO, Southeast Asia is the most open subregion in the world in terms of tourist visa requirements (Table 6). About $33 \%$ of the world's population can obtain a tourist visa on arrival, and $26 \%$ are not required to obtain a visa when traveling for tourism. ${ }^{23}$

28. CLMV have all endorsed the ASEAN Framework Agreement on Visa Exemption, which exempts ASEAN citizens who hold valid national passports from visa requirements to visit other ASEAN countries party to the agreement for a period of stay of up to 14 days. The World Economic Forum ranks Cambodia as the most open among CLMV and second in ASEAN after the Philippines. Visa policies and procedures in Viet Nam and Myanmar are assessed as less facilitative; however, the low openness ranking for Myanmar does not consider deployment of the country's new electronic visa and expanded visa on arrival programs. ${ }^{24}$

22 The bridge is situated in the GMS East-West Economic Corridor.

23 United Nations World Tourism Organization. 2014. Visa Openness Report 2014. Madrid

24 World Economic Forum. 2015. The Travel and Tourism Competitiveness Report 2015. Geneva. 
Table 6: Visa Openness, 2013-2015

\begin{tabular}{|c|c|c|c|}
\hline & $\begin{array}{l}\text { Rank } 2013 \\
(1-140)\end{array}$ & $\begin{array}{c}\text { Rank } 2015 \\
(1-141)\end{array}$ & $\begin{array}{c}\text { Change 2013-2015 } \\
(+/-)\end{array}$ \\
\hline Cambodia & 30 & 8 & +22 \\
\hline Lao PDR & --- & 23 & --- \\
\hline Myanmar & --- & 132 & --- \\
\hline Viet Nam & 15 & 119 & -104 \\
\hline Brunei Darussalam & 104 & --- & --- \\
\hline Indonesia & 100 & 28 & +72 \\
\hline Malaysia & 3 & 33 & -30 \\
\hline Philippines & 7 & 2 & +5 \\
\hline Singapore & 5 & 20 & -15 \\
\hline Thailand & 90 & 25 & +65 \\
\hline
\end{tabular}

--- = data not available, Lao PDR = Lao People's Democratic Republic.

Source: World Economic Forum.

\section{Information and Communication Technology}

29. ICT has reshaped the way consumers plan, purchase, and share experiences about tourism products and services. According to the Boston Consulting Group, more than $95 \%$ of travelers use digital resources for travel planning and consumption, and to share information during and after a trip. ${ }^{25}$ This is influenced by increasing rates of fixed-line and mobile internet usage, the falling cost of internet access, and the rising popularity of online travel agents and social media. For example, TripAdvisor's various branded sites reach 340 million unique monthly visitors and contain more than 225 million reviews covering 4.9 million accommodations, restaurants, and attractions. ${ }^{26}$ In the 12-month period ending 5 June 2015, there were about 500 million active Baidu users and 1.4 billion Facebook users; 29 billion images were uploaded to Instagram and 1.3 trillion videos were viewed on YouTube. ${ }^{27}$ This clearly shows the importance of ICT and social media to the travel and tourism industry. Apart from being an effective tool to promote tourism, ICT modernization supports inclusive growth by creating opportunities for SMEs to affordably connect with global markets. Table 7 summarizes the status of key ICT indicators in ASEAN.

30. Examples of how ICT is being used by government and the private sector to support travel and tourism in CLMV includes the introduction of electronic visas (Cambodia, Myanmar, and Viet Nam), the use of government and private websites for destination marketing, online advertising, business listings on online travel agents, and the use of peer-to-peer sharing economy websites.

\footnotetext{
25 J. Guggenheim et al. 2014. Travel Goes Mobile. Boston Consulting Group.

26 Tripadvisor.com. Accessed 5 June 2015.

27 Internetlive.com. Accessed 5 June 2015.
} 


\section{Table 7: Information and Communication Technology- Key Indicators, 2014/2015}

\begin{tabular}{|l|c|c|c|c|c|c|}
\hline & $\begin{array}{c}\text { Networked } \\
\text { Readiness } \\
\text { Index } \\
(1-143)\end{array}$ & $\begin{array}{c}\text { Internet } \\
\text { Users } \\
\text { (million) }\end{array}$ & $\begin{array}{c}\text { Internet Use } \\
\text { Annual } \\
\text { Growth } \\
(\%)\end{array}$ & $\begin{array}{c}\text { Mobile } \\
\text { Broadband } \\
\text { (per 100 people) }\end{array}$ & $\begin{array}{c}\text { National } \\
\text { Tourism } \\
\text { Organization } \\
\text { Global Website } \\
\text { Ranking }\end{array}$ & $\begin{array}{c}\text { Airbnb } \\
\text { Listings } \\
\text { (no.) }\end{array}$ \\
\hline Cambodia & 110 & 0.8 & 10 & 10 & $5,990,443$ & 716 \\
\hline Lao PDR & 97 & 0.7 & --- & 3 & 749,291 & 68 \\
\hline Myanmar & 139 & 0.6 & 9 & 1 & $1,495,671$ & 115 \\
\hline Viet Nam & 85 & 40 & 9 & 83 & 309,432 & $>1,000$ \\
\hline Brunei Darussalam & --- & 0.3 & 9 & --- & 573,482 & 23 \\
\hline Indonesia & 79 & 42 & 9 & 24 & 47,748 & $>1,000$ \\
\hline Malaysia & 32 & 12 & 16 & 13 & 75,956 & $>1,000$ \\
\hline Philippines & 76 & 39 & 10 & --- & 119,600 & $>1,000$ \\
\hline Singapore & 1 & 4.5 & 10 & 149 & 36,963 & $>1,000$ \\
\hline Thailand & 67 & 19 & 8 & 52 & 53,313 & $>1,000$ \\
\hline
\end{tabular}

--- = data not available, Lao PDR = Lao People's Democratic Republic.

Note: Numbers are rounded. Viet Nam's mobile subscription rate is based on 2012 data. Global website ranking is calculated by the Web analytics firm Alexa, using a proprietary methodology that combines a site's estimated average number of daily unique visitors and its estimated number of page views over the previous three months. Airbnb is a sharing economy website focused on accommodation rentals.

Sources: World Economic Forum; alexa.com; internetlive.com

\section{4. $\quad$ Rising Affluence of Developing Asia}

31. Across developing Asia, GDP rose by 5.9\% in 2015 and is forecast to slow slightly, to $5.7 \%$, during 2016-2017. However, following the establishment of the ASEAN Economic Community, Southeast Asia is expecting growth to strengthen from 4.4\% in 2015 to $4.8 \%$ in $2017 .{ }^{28}$ Gross national income per capita in all ASEAN countries has already reached the levels needed to sustain surging intraregional tourism, and medium-haul leisure travel is affordable for many consumers in the large outbound-generating markets of Japan, the Republic of Korea, and the PRC (Table 8). Increasing wage employment with paid annual leave entitlements, together with Asia's high affinity for travel and tourism, provide further impetus for continued expansion of the tourism industry. Increased government spending on social programs such as health insurance and pensions is also positively influencing tourism growth by reducing the need for precautionary savings, which is highly relevant for aging consumers in Thailand, the Republic of Korea, Japan, and the PRC.

28 ADB. 2016. Asian Development Outlook 2016: Asia's Potential Growth. Manila. 
Table 8: Economic Factors Enabling Outbound Tourism

\begin{tabular}{|l|c|c|c|c|c|}
\hline & $\begin{array}{c}\text { Gross National } \\
\text { Income } \\
\text { per Capita } \\
(\$)\end{array}$ & $\begin{array}{c}\text { Gross Domestic } \\
\text { Product } \\
\text { Growth Rate } \\
(\%)\end{array}$ & $\begin{array}{c}\text { Average } \\
\text { Monthly } \\
\text { Wage } \\
(\$)\end{array}$ & $\begin{array}{c}\text { Annual } \\
\text { Paid Leave } \\
\text { Entitlement } \\
(\text { days })\end{array}$ & $\begin{array}{c}\text { Eligible Population } \\
\text { Receiving a } \\
\text { Pension } \\
(\%)\end{array}$ \\
\hline Cambodia & 1,020 & 7.0 & 121 & 18 & 5.0 \\
\hline Lao PDR & 1,660 & 6.7 & --- & 15 & 5.6 \\
\hline Myanmar & 1,270 & 7.2 & --- & 10 & --- \\
\hline Viet Nam & 1,890 & 6.0 & 197 & $12-18$ & 34.5 \\
\hline Brunei Darussalam & 37,320 & -1.1 & --- & 7 & 87.0 \\
\hline Indonesia & 3,630 & 4.8 & 183 & 12 & 8.1 \\
\hline Malaysia & 11,120 & 5.0 & 651 & $8-16$ & --- \\
\hline Philippines & 3,500 & 5.8 & 215 & 5 & --- \\
\hline Singapore & 55,150 & 2.0 & 3,694 & $7-14$ & --- \\
\hline Thailand & 5,780 & 2.8 & 391 & 6 & 81.7 \\
\hline Bangladesh & 1,080 & 6.6 & --- & 10 & 31.7 \\
\hline India & 1,570 & 7.6 & 215 & 12 & 24.1 \\
\hline Japan & 42,000 & 0.1 & 3,320 & $10-20$ & 80.3 \\
\hline Korea, Republic of & 27,090 & 2.6 & 2,841 & 15 & 77.6 \\
\hline PRC & 7,400 & 6.9 & 613 & $6-16$ & 74.4 \\
\hline
\end{tabular}

--- = data not available, Lao PDR = Lao People's Democratic Republic, PRC = People's Republic of China.

Sources: International Monetary Fund. 2014. World Economic Outlook Database; International Labour Organization; World Bank. 2016. World Development Indicators; ADB. 2016. Asian Development Outlook 2016: Asia's Potential Growth. Manila.

\section{E. Core Tourism Sector Issues, Causes, and Effects}

32. CLMV all have made good progress in promoting tourism growth since 2005. At the same time, the countries suffer from a weak business-enabling environment, human resources constraints, inadequate last-mile transport infrastructure, and insufficient protection of the environment and cultural heritage assets. These constraints lower the overall tourism competitiveness in CLMV and hold back the development of potentially lucrative market linkages between tourism and other sectors. The results are reduced economic benefits, environmental degradation, and persistent inequality between gateway and secondary destinations. Rather than focusing on simply increasing visitor numbers in countries, efforts should shift toward generating and retaining more income from tourism, better balancing the distribution of benefits within CLMV and among ASEAN countries, and controlling negative impacts. Appendix 1 presents the problem tree for tourism in CLMV.

\section{Enabling Environment}

33. Despite some improvement in recent years, the World Bank's Doing Business Report and the World Economic Forum's Travel \& Tourism Competitiveness Index (2015) gave CLMV low rankings for ease of doing business (Table 9 ). Entrepreneurs face lengthy and complicated business and property registration processes, unpredictable tax policies, and ineffective contract enforcement. Local tourism enterprises in the Lao PDR and Myanmar commonly mention lack of access to affordable credit as a 
Table 9: Constraints on the Business-Enabling Environment

\begin{tabular}{|l|c|c|c|c|}
\hline & Cambodia & Lao PDR & Myanmar & Viet Nam \\
\hline World Bank Ease of Doing Business (1-189) & & & & \\
\hline Overall rank & 135 & 148 & 177 & 78 \\
\hline Starting a business & 184 & 154 & 189 & 125 \\
\hline Dealing with construction permits & 183 & 107 & 130 & 22 \\
\hline Registering property & 100 & 77 & 151 & 33 \\
\hline Getting credit & 12 & 116 & 171 & 36 \\
\hline Paying taxes & 90 & 129 & 116 & 173 \\
\hline Enforcing contracts & 178 & 99 & 185 & 47 \\
\hline World Economic Forum Travel \& Tourism Competitiveness Index (1-141) & 105 & 84 & 131 & 73 \\
\hline Overall enabling environment & 129 & 56 & 135 & 66 \\
\hline Business environment & 112 & 108 & 101 & 83 \\
\hline Health and hygiene & 61 & 47 & 83 & 102 \\
\hline Effectiveness of marketing and country branding & & & \\
\hline
\end{tabular}

Lao PDR = Lao People's Democratic Republic.

Sources: World Bank. 2014. Doing Business 2015: Going Beyond Efficiency. Washington, DC; World Economic Forum. 2015.

The Travel and Tourism Competitiveness Report 2015. Geneva.

key concern. These constraints impede private investment in facilities and services needed to attract higher-spending visitors, particularly to secondary destinations. Likewise, low rankings for health and hygiene due to problems with food safety, a high incidence of traffic accidents, and inadequate medical facilities undermine higher-spending leisure travelers' confidence in visiting CLMV. Despite growing government interest in public-private partnerships to expand infrastructure and social services that could help improve tourism competitiveness, the number of completed transactions outside the energy sector is low because of incomplete legal and regulatory frameworks, uncertain access to suitable land, lack of proactive project identification, and the scarcity of long-term affordable finance. ${ }^{29}$

34. Ineffective tourism marketing weakens the business-enabling environment by impeding CLMV's ability to attract higher-spending markets and counter seasonality. Consequently, there are large differences in visitor arrivals between the peak months (December and January) and the low season months (May and June). The largest variation is in Cambodia (47\%), followed by Viet Nam (38\%), Myanmar (41\%), and the Lao PDR (27\%). Highly irregular demand causes cash flow problems for hotels, guesthouses, and tour operators, which leads to seasonal layoffs that can make employment in the subsectors unattractive to talented workers. Key constraints are insufficient public and private funding, weak coordination among tourism industry stakeholders, and low capacity to design and implement effective destination marketing campaigns. ${ }^{30}$

29 ADB. 2012. Assessment of Public-Private Partnerships in Viet Nam: Constraints and Opportunities. Manila; ADB. 2012. Assessment of Public-Private Partnerships in Cambodia: Constraints and Opportunities. Manila.

30 Mekong Tourism Coordinating Office. 2015. Experience Mekong: Greater Mekong Subregion Tourism Marketing Strategy and Action Plan 2015-2020. Bangkok. 


\section{Human Resources}

35. Tourism is a labor-intensive, place-dependent economic activity that directly employed about 4.6 million people in CLMV in 2015. Continued rapid growth in visitor arrivals could create nearly 700,000 additional new jobs by 2020, mainly in diverse small and medium-sized enterprises (SMEs) that provide goods and services consumed by visitors. ${ }^{31}$ Industry stakeholders report that the need for quality human resources far outstrips supply, and the lack of well-trained workers is one of the main barriers to improving tourism service quality and competitiveness. Selected indicators for education, training, and literacy substantiate these concerns (Table 10). Cambodia, the Lao PDR, and Myanmar all show substantial deficiencies in secondary and tertiary enrollment compared to other ASEAN countries, as well as low enrollment in technical and vocational education and training (TVET).

\section{Table 10: Education, Training, and Literacy in the Association of Southeast Asian Nations (\%)}

\begin{tabular}{|c|c|c|c|c|c|c|c|}
\hline & $\begin{array}{l}\text { Literacy } \\
\text { Rate, } \\
\text { Ages 15+ }\end{array}$ & $\begin{array}{l}\text { Primary } \\
\text { Net } \\
\text { Enrollment } \\
\text { Rate } \\
\text { (total) }\end{array}$ & $\begin{array}{l}\text { Secondary } \\
\text { Net } \\
\text { Enrollment } \\
\text { Rate } \\
\text { (total) }\end{array}$ & $\begin{array}{c}\text { TVET } \\
\text { Enrollment as a } \\
\text { Share of Total } \\
\text { Secondary } \\
\text { Enrollment }\end{array}$ & $\begin{array}{l}\text { Female } \\
\text { Share of } \\
\text { TVET } \\
\text { Enrollment }\end{array}$ & $\begin{array}{l}\text { Tertiary } \\
\text { Gross } \\
\text { Enrollment } \\
\text { Rate } \\
\text { (total) }\end{array}$ & $\begin{array}{c}\text { Public } \\
\text { Expenditure } \\
\text { on Education } \\
\text { ( } \% \text { of gross } \\
\text { domestic product) }\end{array}$ \\
\hline Cambodia & 73.9 & 98.4 & 38.2 & 2.3 & 47.0 & 15.8 & 2.6 \\
\hline Lao PDR & 72.2 & 95.9 & 41.4 & 0.8 & 54.0 & 16.7 & 2.8 \\
\hline Myanmar & 92.7 & --- & 47.0 & --- & --- & 13.8 & 0.8 \\
\hline Viet Nam & 93.4 & 98.1 & --- & --- & --- & 24.6 & 6.3 \\
\hline Brunei Darussalam & 95.4 & 91.7 & 94.7 & 11.4 & 49.6 & 24.3 & 3.3 \\
\hline Indonesia & 92.8 & 93.7 & 74.8 & 18.0 & 42.0 & 27.2 & 2.8 \\
\hline Malaysia & 93.1 & 97.0 & 66.3 & 6.8 & 42.5 & 36.0 & 5.9 \\
\hline Philippines & 95.4 & 88.2 & 61.4 & --- & --- & 28.2 & 2.7 \\
\hline Singapore & 95.9 & --- & --- & 11.6 & 35.1 & --- & 3.2 \\
\hline Thailand & 93.5 & 95.6 & 79.5 & 15.4 & 41.5 & 51.4 & 5.8 \\
\hline
\end{tabular}

--- = data not available, Lao PDR = Lao People's Democratic Republic, TVET = technical and vocational education and training.

Sources: United Nations Educational, Scientific and Cultural Organization (UNESCO) Institute for Statistics. Table adapted from International Labour Organization and ADB. 2014. ASEAN Community 2015: Managing integration for better jobs and shared prosperity. Bangkok.

36. Although CLMV all have made progress in upgrading their TVET systems, the high demand for skilled tourism workers underscores the need to further expand access to quality education and training that is relevant to tourism industry needs. Likewise, there is a need to upgrade the skills, qualifications, and foreign language aptitude of incumbent workers to facilitate career progression. Efforts should focus on (i) expanding the number and geographic spread of quality public and private TVET facilities; (ii) increasing professional development for teachers; (iii) improving collaboration between government and private industry to develop and implement competencybased curriculum and certification frameworks; (iv) expanding training courses that are tailored to the time and resource constraints of learners; and ( $v$ ) increasing enrollment, with due consideration for needs-based scholarships to ensure inclusivity. Public information systems and social networks should be used to help change widely held negative perceptions about pursuing a career in the tourism industry.

\footnotetext{
31 See World Travel \& Tourism Council. 2015. Travel and Tourism Economic Impact Reports for Cambodia, the Lao PDR, Myanmar, and Viet Nam.
} 
37. CLMV endorsed the ASEAN Mutual Recognition Arrangement on Tourism Professionals (MRA-TP) in 2012 to complement national efforts to improve the quality of tourism services and facilitate labor mobility. The MRA-TP provides clear standards for developing competency-based training and a common assessment system. It includes professions in hotel and travel services (e.g., housekeeping, front office staffing, food and beverage services, food production, and travel agency and tour operations) covering 32 job titles and 52 specific qualifications based on common labor divisions. Although the MRA-TP is recognized as an important framework to help deepen regional cooperation in tourism and boost tourism competitiveness, implementation of the system is delayed due to funding and capacity shortages. As of late 2015, only Indonesia, Malaysia, Myanmar, the Philippines, Singapore, Thailand, and Viet Nam have established national tourism professional certification boards. Across ASEAN, there are fewer than 200 certified master trainers and master assessors for housekeeping, food production, food and beverage services, and front office divisions, while national trainers and assessors are yet to be trained and certified in CLMV. ${ }^{32}$ Apart from the need to train and certify more trainers and assessors in all labor divisions, other pending issues are (i) establishment of the proposed regional secretariat for MRA-TP implementation, (ii) establishment of professional certification boards in all ASEAN countries, (iii) availability of MRA-TP's common curriculum and training courses in national TVET schools, (iv) establishment of an ASEAN tourism professional registration system, and ( $v$ ) registration of certified tourism professionals in a regional database. Raising awareness among government, industry, and labor about the benefits of implementing the MRA-TP is also needed.

\section{Infrastructure}

38. Quality transport infrastructure is essential to facilitate tourist movements between countries and to attractions within a country. Equally important for tourism competitiveness are quality environmental infrastructure and services to support the collection, treatment, and storage of solid waste and wastewater; availability of piped clean water supply; and access to reliable electricity. CLMV have all made good progress in upgrading air transport infrastructure in gateway cities, building transnational highways, and expanding access to public utilities in major urban areas. However, infrastructure improvements and service delivery in secondary destinations has not kept pace with demand, mainly due to funding and capacity constraints for construction and maintenance, low population density in rural areas, and limited decentralized planning. As a result, CLMV lag behind Asia-Pacific benchmarks for infrastructure competitiveness and health and hygiene (Table 11).

39. Insufficient transport infrastructure and poor environmental services hold back sustainable and more inclusive tourism growth in two ways. First, lacking well-maintained airports, ports, roads, sanitation, wastewater treatment, flood protection, and piped water supply, many secondary destinations are unable to attract private investment in quality tourist service infrastructure. This discourages visitors from venturing off the beaten track and perpetuates current patterns of imbalanced growth. For example, Phnom Penh and Siem Reap, with relatively good urban services, account for about $60 \%$ of Cambodia's total accommodation stock and half of the country's international visitor arrivals. In comparison, the seaside town of Kep-with good tourism potential but lacking a piped water supply and adequate sanitation-receives only $1.1 \%$ of international visitors. Similarly, Vientiane Capital has 25\% of the Lao PDR's hotel rooms and receives 37\% of international visitors. The disparity is even greater in Myanmar, where Yangon receives more than $90 \%$ of international overnight visitors and has $31 \%$ of the country's total accommodation stock (Table 12).

32 Y. Fukunaga. 2015. Assessing the Progress of ASEAN MRAs on Professional Services. Jakarta: Economic Research Institute for ASEAN and East Asia. 
Table 11: Competitiveness Rankings for Infrastructure, Health, and Hygiene

\begin{tabular}{|l|c|c|c|c|c|c|c|c|}
\hline & \multicolumn{2}{|c|}{ Air Transport } & \multicolumn{2}{c|}{ Ground and Ports } & Tourist Services & \multicolumn{2}{c|}{$\begin{array}{c}\text { Health and } \\
\text { Hygiene }^{\mathrm{a}}\end{array}$} \\
\hline & Value $^{\mathrm{b}}$ & Rank $^{\mathrm{c}}$ & Value $^{\mathrm{b}}$ & Rank $^{\mathrm{c}}$ & Value $^{\mathrm{b}}$ & Rank $^{\mathrm{c}}$ & Value $^{\mathrm{b}}$ & Rank $^{\mathrm{c}}$ \\
\hline Cambodia & 2.1 & 103 & 2.6 & 116 & 2.9 & 108 & 3.9 & 112 \\
\hline Lao PDR & 2.3 & 89 & 3.0 & 96 & 3.2 & 97 & 4.3 & 108 \\
\hline Myanmar & 2.0 & 115 & 2.2 & 132 & 2.1 & 137 & 4.4 & 101 \\
\hline Viet Nam & 2.7 & 68 & 3.1 & 87 & 2.9 & 105 & 5.0 & 83 \\
\hline Asia-Pacific Average & 3.58 & & 3.83 & & 3.68 & & 5.14 & \\
\hline
\end{tabular}

Lao PDR = Lao People's Democratic Republic.

a Tourist services infrastructure includes hotels, resorts, and other facilities developed especially to respond to visitor demand. Two of six indicators for health and hygiene are concerned with sanitation and clean water supply.

b Value range $=1-7$, with a higher number indicating better performance.

c Rank =1-141, with lower number indicating better performance.

Source: World Economic Forum. 2015. The Travel and Tourism Competitiveness Report 2015. Geneva.

Table 12: Tourism Services Intensity and International Visitor Arrivals

\begin{tabular}{|c|c|c|c|c|c|c|c|}
\hline \multirow[b]{2}{*}{ Destination } & \multicolumn{3}{|c|}{ Accommodations } & \multicolumn{2}{|c|}{$\begin{array}{l}\text { International } \\
\text { Tour Operators }\end{array}$} & \multicolumn{2}{|c|}{$\begin{array}{l}\text { International } \\
\text { Visitor Arrivals }\end{array}$} \\
\hline & $\begin{array}{l}\text { No. of } \\
\text { Rooms }\end{array}$ & $\begin{array}{l}\text { Share } \\
(\%)\end{array}$ & $\begin{array}{l}\text { Occupancy } \\
\text { (\%) }\end{array}$ & $\begin{array}{c}\text { Companies } \\
\text { (no.) }\end{array}$ & $\begin{array}{l}\text { Share } \\
(\%)\end{array}$ & No. & $\begin{array}{l}\text { Share } \\
(\%)\end{array}$ \\
\hline Phnom Penh & 14,661 & 28.6 & 60 & 325 & 53.0 & $1,972,879$ & 46.9 \\
\hline Siem Reap & 15,228 & 29.7 & 70 & 264 & 43.1 & $2,237,286$ & 53.1 \\
\hline Preah Sihanouk & 5,431 & 10.4 & 70 & 15 & 2.4 & 358,639 & 6.4 \\
\hline Kep & 775 & 1.5 & 60 & --- & --- & 46,840 & 1.1 \\
\hline Vientiane & 14,627 & 25.4 & 74 & 216 & 58.7 & $1,737,979$ & 37.1 \\
\hline Luang Prabang & 6,891 & 12.0 & 73 & 57 & 15.5 & 531,327 & 11.3 \\
\hline Champasak & 5,234 & 9.0 & 56 & 29 & 7.9 & 611,244 & 13.0 \\
\hline Houaphanh & 1,111 & 1.9 & 51 & 1 & 0.3 & 34,493 & 0.7 \\
\hline Yangon & 15,424 & 30.8 & 72 & 795 & 96.0 & $1,180,682$ & 90.7 \\
\hline Mandalay & 6,788 & 13.6 & 73 & 25 & 4.0 & 553,572 & 42.5 \\
\hline Bagan & 2,565 & 5.1 & 70 & --- & --- & 351,427 & 27.0 \\
\hline Mawlymyine & 730 & 1.5 & 72 & --- & --- & 115,087 & 12.1 \\
\hline Ha Noi & 18,630 & 6.7 & 55 & 482 & 42.6 & $2,100,000$ & 30.7 \\
\hline Ho Chi Minh City & 40,202 & 14.5 & 69 & 388 & 34.3 & $3,800,000$ & 55.5 \\
\hline Da Nang & 10,570 & 3.8 & 51 & 40 & 3.5 & 630,908 & 9.2 \\
\hline Quang Ninh & 9,517 & 3.4 & 70 & 39 & 3.4 & $2,491,000$ & 36.4 \\
\hline
\end{tabular}

--- = data not available.

Notes: Accommodations include the combined number of hotel and guesthouse rooms. Border gate visitors are not included for Myanmar calculations. Percentages are based on country totals, except Myanmar tour operators, which include members of Myanmar Tourism Federation only.

Sources: National tourism organization statistics reports 2012-2015; New Crossroads Asia. 2015. Myanmar: All That Matters. Issue 5, October 2015. Yangon; ADB estimates. 
40. The second problem is that poor transport infrastructure and environmental services are easily overwhelmed by a surge in visitor arrivals, leading to incomplete collection and treatment of solid waste and wastewater, shortages of piped clean water, and traffic congestion. This puts future tourism growth at risk and causes environmental degradation, economic losses, and inconvenience for residents. For example, in Luang Prabang, Lao PDR, where the number of annual international visitor arrivals is about ten times the local population and growing by $14 \%$ per year, residents produce an average of 0.63 kilograms of solid waste per capita per day, but international visitors generate nearly twice as much, disproportionally overburdening the town's solid waste management system. Luang Prabang and its peri-urban villages generate 68 tons of solid waste per day, but only $66 \%$ is collected and disposed in the town's controlled landfill, less than $6 \%$ is recycled, and about 20 tons per day are left to accumulate in the environment. ${ }^{33}$ International visitors also consume large volumes of water, ranging from 300 liters per person per day-triple that of local residents-to 880 liters per person per day for luxury travelers. ${ }^{34}$ Consequently, Luang Prabang has 3.5 times the national average of unplanned piped water supply interruptions. ${ }^{35}$ Overall, the annual economic losses resulting from lower visitor numbers and reduced spending by visitors who become sick from diseases related to poor sanitation and hygiene ranges from $\$ 17.3$ million in the Lao PDR to $\$ 68.6$ million in Viet Nam and $\$ 73.7$ million in Cambodia. ${ }^{36}$

\section{Protection of Cultural and Natural Assets}

41. Natural and cultural assets, including historic sites, cultural industries, national parks, and urban green space, make a destination attractive to visitors and livable for residents. Recognizing that protection of such assets is essential to maintaining the cultural values and ecosystem services that are important to many facets of their economies, CLMV have legally established extensive protected area systems in conjunction with other ASEAN countries (Table 13). Recreation and tourism feature prominently in the management plans of most protected areas.

42. Since accepting the Convention Concerning the Protection of the World Cultural and Natural Heritage (the World Heritage Convention), CLMV have added 13 properties to the United Nations Educational, Scientific and Cultural Organization (UNESCO) list of World Heritage Sites. All are striving to increase the number of listings and prioritize funding and technical expertise for conservation. CLMV are active parties to the ASEAN Declaration on Heritage Parks and contain about half of the protected areas selected under the initiative. ${ }^{37}$

33 Japan International Cooperation Agency. 2012. Laos Pilot Program for Narrowing the Development Gap towards ASEAN Integration. Vientiane.

34 United Nations Environment Programme. 2003. A Manual for Water and Waste Management: What the Tourism Industry Can Do to Improve Its Performance. Paris; ADB. 2013. Report and Recommendation of the President to the Board of Directors: Proposed Loan and Administration of Grant to the Lao People's Democratic Republic-Water Supply and Sanitation Sector Project. Manila.

35 ADB. 2014. Consultant's Report. Technical Assistance 7919-LAO: Strengthening Urban Water Supply Regulation. Manila.

36 World Bank. 2008. Economic Impacts of Sanitation in Southeast Asia. Jakarta; World Bank. 2009. Economic Impacts of Sanitation in Lao PDR. Water and Sanitation Program.

37 ASEAN Secretariat. 2003. ASEAN Declaration on Heritage Parks. Jakarta. 


\section{Table 13: Natural and Cultural Protected Areas in the Association of Southeast Asian Nations}

\begin{tabular}{|c|c|c|c|c|c|}
\hline & \multicolumn{3}{|c|}{ Natural Protected Areas } & \multirow{2}{*}{$\begin{array}{l}\text { United Nations } \\
\text { Educational, } \\
\text { Scientific and } \\
\text { Cultural Organization } \\
\text { World Heritage Sites }\end{array}$} & \multirow[b]{2}{*}{$\begin{array}{c}\text { Association } \\
\text { of Southeast } \\
\text { Asian Nations } \\
\text { Heritage Parks }\end{array}$} \\
\hline & No. & $\begin{array}{l}\text { Area } \\
\left(\mathrm{km}^{2}\right)\end{array}$ & $\begin{array}{c}\text { Total } \\
\text { Land Area } \\
(\%)\end{array}$ & & \\
\hline Cambodia & 44 & 47,466 & 26 & 2 & 2 \\
\hline Lao PDR & 33 & 38,542 & 17 & 2 & 1 \\
\hline Myanmar & 57 & 48,592 & 7 & 1 & 7 \\
\hline Viet Nam & 223 & 25,153 & 7 & 8 & 5 \\
\hline Brunei Darussalam & 56 & 2,676 & 46 & 0 & 1 \\
\hline Indonesia & 645 & 475,062 & 18 & 8 & 3 \\
\hline Malaysia & 739 & 64,584 & 19 & 4 & 3 \\
\hline Philippines & 559 & 51,884 & 12 & 6 & 7 \\
\hline Singapore & 4 & 44 & 7 & 1 & 2 \\
\hline Thailand & 237 & 102,818 & 21 & 5 & 4 \\
\hline
\end{tabular}

Lao PDR = Lao People's Democratic Republic.

Sources: ASEAN Biodiversity Information Sharing Service, www.aseanbiodiversity.org; International Union for Conservation of Nature, World Database on Protected Areas, www.ProtectedPlanet.net; UNESCO World Heritage Center database, http://whc.unesco.org/en/list/

43. When managed properly, tourism activity in natural protected areas, UNESCO World Heritage Sites, and ASEAN Heritage Parks generates opportunities for local economic diversification and raises public revenue needed for landscape management and preservation of cultural assets. Tourism stimulates creative industries and preservation of indigenous knowledge, which form part of a destination's distinct and competitive identity. However, facilitative tourism policies without proper management controls can generate visitor demand that exceeds the capacity of cultural and natural attractions, leading to resource degradation and a subsequent collapse in tourism growth. ${ }^{38}$

44. Despite an abundance of well-designed management plans, stakeholders mention weak enforcement of laws and regulations, development of extractive industries, expanding commercial agriculture, and wildlife poaching as key threats to tourism development in and around CLMV's natural protected areas. These assertions reflect the findings of regional assessments conducted by the International Centre for Environmental Management, which found that CLMV's protected areas suffer from insufficient government funding, rapid population growth, agricultural encroachment, growing demand for fuel wood, and illegal trade in wildlife, timber, and nontimber forest products. ${ }^{39}$ UNESCO reviews of cultural heritage management practices point out the need for better urban planning and adaptive use of heritage buildings, increased public participation in conservation planning, heritage education for residents and tourists, promotion of cultural industries, reinvestment of taxes and fees into heritage conservation, and more stringent use and enforcement of cultural heritage impact assessments as part of development planning. ${ }^{40}$

\footnotetext{
38 P. Haxton. 2015. A Review of Effective Policies for Tourism Growth, OECD Tourism Papers, 2015/01. Paris.

39 ICEM. 2003. Regional Report on Protected Areas and Development. Queensland.

40 See the UNESCO series, IMPACT: The Effects of Tourism on Culture and the Environment in Asia and the Pacific. Bangkok.
} 
45. Poorly managed tourism growth also can lead to sexual exploitation of children and child labor. According to ECPAT International, increasing numbers of children in Southeast Asia are sexually exploited by local and foreign visitors who make use of facilities developed for tourism to gain access to children. ${ }^{41}$ Children working as street vendors, as tour guides, and in entertainment venues are especially vulnerable to abuse, with elevated risk of becoming entangled in sex work and trafficking. These risks are higher for children living near borders, casinos, and special economic zones. ${ }^{42}$ Although poverty, migration, parental absence, and abusive household situations are among the main contributors to vulnerability, ending sexual exploitation of children by tourists requires more effort to (i) educate visitors and industry stakeholders about the factors that make children susceptible to abuse, (ii) strengthen legal frameworks to allow increased criminal prosecution of traveling sex offenders in tourist destinations and countries of origin, (iii) improve cooperation and investigative capacity of international law enforcement agencies, and (iv) promote tourism products and services that align with child-safe tourism principles. ${ }^{43}$

\section{Climate Change}

46. The United Nations Framework Convention on Climate Change (1992) and the subsequent Paris Agreement (2015) unify international efforts to mitigate the release of greenhouse gases into the atmosphere and adapt to the negative impacts of climate change. The main purpose is to limit global temperature rise during this century to well below 2 degrees Celsius above preindustrial levels and to pursue efforts to hold the temperature increase to 1.5 degrees Celsius.

47. In CLMV, the major negative effects of climate change are increased incidence of severe weather events, changing rainfall patterns, rising temperatures, more frequent forest fires, and sea level rise. These are putting increased strain on transport infrastructure and urban services essential for tourism, threaten agricultural output, and may increase the frequency and severity of communicable disease outbreaks. With tourism highly dependent on pristine beaches, coastal cities, agriculture, forests, and other natural attractions, countering climate change is an urgent priority.

48. Tourism and travel generate greenhouse gas emissions-mainly carbon dioxide $\left(\mathrm{CO}_{2}\right)$-by increasing incremental consumption of energy-intensive transport and accommodation services. Overall, tourism contributes about $5 \%$ to global $\mathrm{CO}_{2}$ emissions, and transportation (mostly aviation) comprises $75 \%$ of tourism's carbon footprint. ${ }^{44}$ Technological improvements such as fuel efficiency, alternative fuels, and renewable energy are required to lower transportation emissions, together with regulatory and market-based measures that incentivize or require the use of lower-carbon technologies. On the demand side, consumer behavior change can be promoted to lower emissions. Tourists should be encouraged to choose lower-carbon travel options, to offset emissions, and to purchase environmentally friendly products and services.

49. The accommodation subsector accounts for about $20 \%$ of tourism's $\mathrm{CO}_{2}$ emissions. With improved energy efficiency, better maintenance, and wider access to renewable energy sources, accommodations could emit 30\%-40\% less $\mathrm{CO}_{2}$. This highlights the importance of green accommodation standards and resource-efficient building design and certification programs.

${ }^{41}$ ECPAT International. 2014. The Commercial Exploitation of Children in East and Southeast Asia: Developments, Progress, Challenges and Recommended Strategies for Civil Society. Bangkok.

42 United States Department of State. 2014. Trafficking in Persons Report 2014. Washington, DC.

43 See World Vision Australia. 2013. The Child Safe Traveler. Project Childhood Prevention Pillar and www.childsafetourism.org.

${ }^{44}$ United Nations World Tourism Organization. 2008. Climate Change and Tourism Responding to Global Challenges. Madrid. 
CLMV are committed to implementing the ASEAN Green Hotel Standard, but more needs to be done to strengthen building codes, increase the generation and distribution of renewable energy, and improve the energy efficiency of urban services such as water supply and wastewater treatment.

50. Tourism destinations also need to accelerate climate change adaptation efforts. This requires more financing and technical expertise to design and construct climate-resilient infrastructure and retrofit existing facilities. Businesses must adapt to changing demand patterns, and all industry stakeholders must implement resource conservation measures, especially water, forest, and coastal ecosystem conservation. As tour operators interact with the entire tourism supply chain, they can help influence government, consumers, and businesses to implement mitigation and adaptation measures.

51. CLMV's intended nationally determined contributions support their commitment to counter climate change. Some key mitigation objectives are to (i) increase forest cover and improve biodiversity conservation; (ii) expand rural electrification and increase the share of renewable energy generation and consumption; (iii) improve transport network planning, public transport systems, and fuel efficiency standards; and (iv) strengthen the legal framework and implementation of national strategies to address climate change. The focus of adaptation activities are to (i) promote climateresilient agriculture, (ii) improve forest management, (iii) improve water resource management and integrated coastal zone management, (iv) retrofit and construct climate-resilient urban and transport infrastructure, (v) modernize hydrometeorological observatories and forecasting systems, and (vi) improve communicable disease surveillance and control. Education and awareness about climate change mitigation actions and adaptation will be mainstreamed in all sectors, including tourism.

\section{Market Linkages}

52. The tourism value chain comprises a range of industries that produce goods and services consumed directly and indirectly by visitors, both international and domestic. Most recognizable are air travel, accommodation, tours and tour operations, restaurants, retail shops, ground transport, and tourist attractions such as museums and waterfalls. Less evident but equally important in terms of tourism's potential net income contribution to a country are farmers (suppliers of food and many raw materials used to produce crafts); construction and manufacturing industries (builders and suppliers of hotels, restaurants, and shopping venues); education and training institutions (trainers of tourism workers); and ICT firms (providing access to the internet and mobile communications).

53. The composition of international tourism expenditure in a destination influences how it benefits an economy. If a high proportion of destination expenditure is spent on imports or if the supply capacity of the destination economy is insufficient to meet additional demand, income multiplier effects will be low. Consequently, foreign exchange "leakage" will be high, resulting in suboptimal net income contributions to the country's economy. ${ }^{45}$

54. In 2005, foreign exchange leakage factors were estimated at $40 \%$ for Cambodia, the Lao PDR, and Myanmar, and at 35\% for Viet Nam, due to the countries' relatively early-stage tourism development, less-diverse economies, and underdeveloped local value chains. Assuming CLMV reduced leakage to 24\% in 2015, as targeted in the GMS Tourism Sector Strategy 2005-2015, there remains significant room for improvement, given that foreign exchange leakage in Thailand and the PRC is estimated at less than $5 \%$ of international tourism expenditure. ${ }^{46}$ Table 14 illustrates

\footnotetext{
45 The term "leakage" refers to the amount spent on importing goods and services to meet the needs of tourists.

${ }^{46}$ ADB. 2005. Consultant's Report. TA-6179: Greater Mekong Subregion Tourism Sector Strategy. Manila.
} 
the potential net income contribution of tourism to CLMV in 2020 under two scenarios. The first assumes no further reductions in the foreign exchange leakage factor during 2015-2020. The second assumes that leakage drops to $18 \%$ in 2020 , resulting in $\$ 50$ million more in net income for the Lao PDR, \$270 million for Cambodia, \$600 million for Myanmar, and \$1.14 billion for Viet Nam.

Table 14: Potential Net Income Contributions from Tourism, 2020

\begin{tabular}{|c|c|c|c|c|}
\hline & $\begin{array}{c}\text { Projected } \\
\text { International } \\
\text { Visitor Arrivals } \\
\text { (no.) }\end{array}$ & $\begin{array}{l}\text { Projected } \\
\text { Expenditure } \\
\text { (\$ billion) }\end{array}$ & $\begin{array}{c}\text { Projected Income } \\
\text { with } 24 \% \text { Foreign } \\
\text { Exchange Leakage } \\
\text { Factor } \\
\text { (\$ billion) }\end{array}$ & $\begin{array}{c}\text { Projected Income } \\
\text { with } 18 \% \text { Foreign } \\
\text { Exchange Leakage } \\
\text { Factor } \\
(\$ \text { billion })\end{array}$ \\
\hline Cambodia & $7,000,000$ & 4.50 & 3.42 & 3.69 \\
\hline Lao PDR & $4,700,000$ & 0.80 & 0.61 & 0.66 \\
\hline Myanmar & $7,500,000$ & 10.10 & 7.68 & 8.28 \\
\hline Viet Nam & $10,500,000$ & 19.00 & 14.44 & 15.58 \\
\hline
\end{tabular}

Lao PDR = Lao People's Democratic Republic.

Sources: $A D B$ and national tourism organization estimates.

55. Increasing net income from tourism requires productivity enhancements and the expansion of diverse small and medium-sized enterprises (SMEs), which need to broaden their supply of local products and services. Helping producers of food, crafts, and other local goods and services access tourism value chains could boost overall spending in destinations, thus providing a larger pool of destination expenditure, more jobs, and potentially higher net income. ${ }^{47}$ To achieve these outcomes, more investment in productive rural infrastructure, urban-rural connectivity, and business support services are needed.

\section{F. Tourism's Linkages to Other Sector, Thematic, and Regional Cooperation Issues}

56. Tourism activity builds synergies with ADB and CLMV government support for agriculture and natural resources, education, energy, transport, water, and other urban infrastructure and services (Table 15). With strong linkages to other sector and thematic issues, tourism (i) provides markets for raw and value-added agricultural products; (ii) generates millions of jobs for school graduates-mostly women; (iii) catalyzes additional public and private investment for roads, ports, airports, and other infrastructure that is used by both tourists and the local population to access services and markets; and (iv) generates taxes and fees to finance infrastructure maintenance and subsidize environmental services. With millions of international visitors crossing CLMV's borders each year, and international visitor expenditure accounting for $28.9 \%$ of Cambodia's total exports and $16.2 \%$ of the Lao PDR's total exports, tourism is a major driver of regional cooperation and integration. On the other hand, if improperly managed, tourism growth can stretch the capacity of transport systems, degrade the environment, and inflate local prices for food and essential goods.

47 For example, the tourist souvenir market in Siem Reap, Cambodia, generates about $\$ 50$ million to $\$ 70$ million per year; however, tourists report they would spend an additional $\$ 60$ million per year if Cambodia-made products that match market demand were available for purchase. 


\section{Table 15: Tourism Linkages to Other Sectors and Synergies}

\begin{tabular}{|c|c|c|}
\hline Sector/Theme & Influence of Tourism & Synergies with Other ADB Operations \\
\hline $\begin{array}{l}\text { Agriculture and } \\
\text { natural resources }\end{array}$ & $\begin{array}{l}22 \text { million international visitors consume } \\
\text { more than } 300 \text { million meals per year. } \\
\text { Agritourism generates additional on-farm } \\
\text { revenue and adds value to farm products. }\end{array}$ & $\begin{array}{l}\text { ADB support to accelerate crop and livestock } \\
\text { commercialization to meet additional demand } \\
\text { for food and agricultural raw materials. }\end{array}$ \\
\hline Education & $\begin{array}{l}700,000 \text { new tourism workers will enter the } \\
\text { workforce from } 2015 \text { to } 2020 \text {. All require } \\
\text { quality education and training. }\end{array}$ & $\begin{array}{l}\text { ADB support to expand the quality of training } \\
\text { facilities and courses to match service } \\
\text { industry needs. }\end{array}$ \\
\hline Energy & $\begin{array}{l}\text { Expansion of accommodation, entertainment, } \\
\text { and cottage industries and light manufacturing } \\
\text { requires a reliable supply of affordable } \\
\text { electricity. }\end{array}$ & $\begin{array}{l}\text { ADB support for cleaner electricity generation, } \\
\text { power transmission, and energy efficiency. }\end{array}$ \\
\hline Environment & $\begin{array}{l}\text { Poorly managed tourism growth can degrade } \\
\text { the environment and culturally sensitive areas. } \\
\text { Tourism contributes about } 5 \% \text { to annual global } \\
\text { greenhouse gas emissions. Tourism generates } \\
\text { awareness and financial resources for } \\
\text { environmental protection and conservation. }\end{array}$ & $\begin{array}{l}\text { ADB support for biodiversity conservation } \\
\text { corridors, protected area management, } \\
\text { climate change mitigation and adaptation, } \\
\text { and payment for ecosystem services. }\end{array}$ \\
\hline Gender & $\begin{array}{l}\text { Tourism is a major source of women's } \\
\text { employment and economically empowers } \\
\text { women. }\end{array}$ & $\begin{array}{l}\text { ADB support for women's empowerment } \\
\text { and gender mainstreaming in all sectors. }\end{array}$ \\
\hline $\begin{array}{l}\text { Private sector } \\
\text { development }\end{array}$ & $\begin{array}{l}\text { Tourism generates more than } \$ 15 \text { billion } \\
\text { in private investment and about } \$ 22 \text { billion } \\
\text { in destination expenditure annually. }\end{array}$ & $\begin{array}{l}\text { ADB support for small and medium-sized } \\
\text { enterprise development. Proposed Yangon } \\
\text { Urban Renewal and District Cooling Project, } \\
\text { Myanmar. }\end{array}$ \\
\hline $\begin{array}{l}\text { Regional cooperation } \\
\text { and integration }\end{array}$ & $\begin{array}{l}\text { Increased movement of people and goods } \\
\text { across borders, additional trade in services, } \\
\text { and expansion of international transport } \\
\text { connectivity. }\end{array}$ & $\begin{array}{l}\text { ADB support for cross-border transport } \\
\text { agreements, safe labor mobility, cross- } \\
\text { border communicable disease control, trade } \\
\text { facilitation, and border infrastructure. }\end{array}$ \\
\hline Transport & $\begin{array}{l}\text { Tourism activity increases the economic } \\
\text { efficiency of transport investments but can } \\
\text { also overwhelm local transport systems. }\end{array}$ & $\begin{array}{l}\text { ADB support for transnational highways, } \\
\text { urban and rural access roads, airports, ports, } \\
\text { and public transport systems. }\end{array}$ \\
\hline $\begin{array}{l}\text { Water and other } \\
\text { urban infrastructure } \\
\text { and services }\end{array}$ & $\begin{array}{l}\text { Increased demand for piped clean water } \\
\text { supply, solid waste and wastewater treatment, } \\
\text { drainage, flood protection, and pedestrian- } \\
\text { friendly, livable cities. }\end{array}$ & $\begin{array}{l}\text { ADB support to expand the quality } \\
\text { and coverage of urban environmental } \\
\text { services, water supply, and development of } \\
\text { urban green space. }\end{array}$ \\
\hline
\end{tabular}

$\mathrm{ADB}=$ Asian Development Bank.

Sources: ADB, Organization for Economic Cooperation and Development; World Travel and Tourism Council; United Nations World Tourism Organization.

57. Strategic tourism directions for CLMV are closely aligned with the ASEAN Tourism Strategic Plan and the GMS Tourism Sector Strategy. The ASEAN Tourism Strategic Plan's objectives are to enhance the competitiveness of ASEAN as a single destination and to ensure more sustainable and inclusive tourism. The focus is on joint marketing and promotion, product diversification, attracting investment, human resources development, and implementation of regional standards. The plan also aims to expand destination infrastructure, enhance travel facilitation, mainstream community participation and public-private cooperation, ensure safety and security of tourists, protect cultural and natural heritage, and increase environmental protection and responsiveness to climate change. 
ASEAN targets for 2025 include (i) 152 million international visitor arrivals, (ii) $\$ 1,500$ average spending per international visitor/trip, (iii) implementation of Mutual Recognition Arrangement on Tourism Professionals (MRA-TP) benchmarks in all member states, and (iv) 7\% of ASEAN's total direct employment to result from tourism. ${ }^{48}$

58. The GMS Tourism Sector Strategy 2005-2015 set 2015 targets of 52 million international visitor arrivals, $\$ 52.4$ billion in international visitor expenditures, and 7.3 million tourism-related jobs. Strategic programs (i) strengthened GMS marketing and product development; (ii) built human resources, with a focus on enhancing the skills of tourism leaders and trainers; (iii) improved heritage conservation and social impact management; (iv) promoted pro-poor tourism; (v) enhanced private sector participation and partnerships in tourism planning, investment, and marketing; (vi) reduced impediments to travel to and within the GMS; and (vii) improved tourism-related infrastructure. While all strategic targets were achieved, CLMV's share of international arrivals and corresponding expenditure was less than $40 \%$ of the total. A new 10 -year GMS tourism sector strategy is being prepared in 2016 and will set new targets for 2025.

\section{G. Summary of Key Opportunities, Constraints, Development Needs, and Risks}

59. Tourism is a rapidly growing, place-dependent activity that offers enormous opportunities to boost inclusive economic growth. Strengths to build on include CLMV's diverse tourism assets, excellent gateway air and land transport infrastructure, open visa policies, and robust private investment in employment-intensive subsectors. These include accommodations, food and beverage services, tour operations, and local entertainment, all of which create and sustain good jobs and generate income at or close to the point of consumption. The rising affluence of developing Asia, coupled with the region's strong affinity for travel and tourism, is expected to provide continued stimulus for tourism growth into the foreseeable future.

60. Policy makers in CLMV recognize that strategically managed tourism can enhance inclusive economic growth by enabling rural and urban residents to access lifelong salaried employment in service sectors and provide markets for lower-income producers. Tourism generates significant tax revenue that can be reinvested to support social development objectives, improve environmental management, and protect cultural heritage. However, to fully harness and better balance the benefits of tourism, secondary destinations with good tourism potential require more public investment in transport infrastructure to facilitate the movement of tourists into new areas. Secondary destinations also must improve infrastructure that protects the environment and expand environmental services to ensure that destinations remain safe, livable, and competitive. In tandem with infrastructure investment, targeted policy reforms and better tourism education and training are needed to make the business environment more attractive to firms that produce the goods and services demanded by higher-spending visitors.

61. Quality infrastructure, capable human resources, and progressive policies will help mitigate the risks to sustainable and inclusive tourism growth in CLMV. These include environmental degradation, undesirable social impacts such as child-sex tourism, communicable disease outbreaks, insufficient disaster readiness and response, and strong tourism competition from other destinations in Asia and the Pacific.

${ }^{48}$ ASEAN Secretariat. 2016. ASEAN Tourism Strategic Plan 2016-2025. Jakarta. 


\section{Sector Strategy}

\section{A. Government Sector Strategy, Policy, and Plans}

62. The national tourism sector strategies of CLMV focus on infrastructure and service quality improvements to increase tourism expenditure, maximize income and employment generation from tourism and linked industries, and reduce the negative social and environmental impacts of tourism. The main strategic directions and policies are summarized in Table 16. ${ }^{49}$ Priority projects to improve public infrastructure require the most resources, followed by human resource development, negative impact management, marketing and promotion, and travel facilitation.

63. Laws and policies on immigration, transport, construction, and labor strongly influence the regulatory and business environment for tourism. Recognizing that the private sector plays an important role as investors and destination marketers, CLMV's national tourism organizations coordinate strategic planning and policy dialogue with other government agencies and private enterprises through national tourism sector advisory boards, sector working groups, and industry associations. These include the Cambodia Association of Travel Agents, the Cambodia Hotel Association, the Cambodian Tourism Marketing and Promotion Board, the Myanmar Tourism Federation, and the Viet Nam Tourism Advisory Board. Although the Lao PDR presently lacks a national tourism advisory board or similar public-private entity, the Lao Association of Travel Agents and the Lao Hotel and Restaurant Association routinely work with government to address tourismrelated regulatory and policy issues. ${ }^{50}$ Table 17 summarizes the mission and objectives of tourism advisory boards and select industry associations.

64. Participatory processes guided preparation of CLMV's current tourism sector strategies, following international good practice. Strategic directions and activities are demand driven and aligned with the needs of government, the private sector, civil society, and other industry stakeholders, with emphasis on women's empowerment. The sector strategy for Cambodia was adopted by Cambodia's Council of Ministers in 2012. Myanmar's Tourism Master Plan was endorsed by the president's office and cabinet in 2013, after a series of national consultations that involved more than 700 representatives of government, industry associations, civil society organizations, communities, and individual enterprises. Strategies for the Lao PDR and Viet Nam were formulated based on similar consultations and were endorsed in 2011 by the respective prime minister of each country. Overall, CLMV's tourism sector strategies are considered relevant; however, the feasibility of effective implementation varies due to funding and capacity constraints.

\footnotetext{
49 Ministry of Tourism. 2012. Cambodia Tourism Development Strategic Plan 2012-2020. Phnom Penh; Ministry of Hotels and Tourism. 2013. Myanmar Tourism Master Plan 2013-2020. Nay Pyi Taw; Ministry of Information, Culture and Tourism. 2012. Lao PDR Tourism Strategy 2012-2020. Vientiane; Ministry of Culture, Sports and Tourism. 2012. Strategy for Tourism Development in Viet Nam to 2020, Vision to 2030. Ha Noi.

50 The Lao PDR dissolved its public-private Tourism Marketing and Promotion Board shortly after it was launched in 2011.
} 


\section{Table 16: Strategic Directions of Government Tourism Sector Strategies}

\begin{tabular}{|c|c|c|}
\hline Strategy & Strategic Directions & Targets \\
\hline $\begin{array}{l}\text { Cambodia } \\
\text { Tourism } \\
\text { Development } \\
\text { Strategic Plan } \\
\text { 2012-2022 }\end{array}$ & $\begin{array}{l}\text { - Enhance tourism product development and product quality } \\
\text { - Improve marketing and promotion } \\
\text { - Improve travel facilitation, transportation, and regional and } \\
\text { - Improve tourism safety and management of negative } \\
\text { environmental, social, cultural, and economic impacts } \\
\text { - Strengthen legal systems and management mechanisms } \\
\text { - Human resource development }\end{array}$ & $\begin{array}{l}7.5 \text { million } \\
\text { international visitor } \\
\text { arrivals (IVA) } \\
\text { - } \$ 5 \text { billion } \\
\text { international visitor } \\
\text { expenditure } \\
\text { - } 1 \text { million new jobs }\end{array}$ \\
\hline $\begin{array}{l}\text { Lao PDR } \\
\text { National } \\
\text { Tourism Strategy } \\
\text { 2012-2020 }\end{array}$ & $\begin{array}{l}\text { - Increase national income and generate employment for } \\
\text { - Incal people } \\
\text { quality of tourist destinations and products } \\
\text { - Effectively implement regulations, standards, and zoning } \\
\text { - Improve tourism research, information, marketing, and } \\
\text { - Hromotion } \\
\text { - Improve tourism infrastructure and develop products and } \\
\text { circuits that link subnational areas }\end{array}$ & $\begin{array}{ll}\text { - } & 4.5 \text { million IVA } \\
\text { - } & \$ 800 \text { million } \\
& \text { international visitor } \\
& \text { expenditure } \\
\text { - } & 100,000 \text { new jobs }\end{array}$ \\
\hline $\begin{array}{l}\text { Myanmar } \\
\text { Tourism Master } \\
\text { Plan 2013-2020 }\end{array}$ & $\begin{array}{l}\text { - Strengthen the institutional environment for tourism } \\
\text { - } \text { Build human resources and service quality } \\
\text { - } \text { management } \\
\text { - } \text { Develop quality products and services } \\
\text { - } \text { Improve connectivity and tourism-related infrastructure } \\
\text { Build the image, position, and brand of Myanmar }\end{array}$ & $\begin{array}{ll}\text { - } & 7.5 \text { million IVA } \\
\text { - } & \$ 10.2 \text { billion } \\
\text { international visitor } \\
\text { expenditure } \\
\text { - } \quad 1.5 \text { million new jobs }\end{array}$ \\
\hline $\begin{array}{l}\text { Viet Nam } \\
\text { Strategy } \\
\text { for Tourism } \\
\text { Development } \\
\text { to } 2020, \\
\text { Vision to } 2030\end{array}$ & $\begin{array}{l}\text { - Develop tourism into a leading economic sector } \\
\text { - Improve tourism quality, efficiency, brand recognition, } \\
\text { - } \text { and competitiveness } \\
\text { - attracting more high-spending international visitors } \\
\text { - } \text { Protect cultural, historic, and natural resources } \\
\text { - Increase domestic and international tourism investment }\end{array}$ & $\begin{array}{ll}\text { - } & 10.5 \text { million IVA } \\
& \$ 19 \text { billion } \\
\text { international visitor } & \text { expenditure } \\
\text { - } & 900,000 \text { new jobs }\end{array}$ \\
\hline $\begin{array}{l}\text { Joint Action } \\
\text { Plan on CLMV } \\
\text { Tourism } \\
\text { Cooperation } \\
\text { 2016-2018 }\end{array}$ & $\begin{array}{l}\text { - Facilitate travel into and within CLMV } \\
\text { - Strengthen capacity of public officials and private service } \\
\text { - Increase participation of the private sector and } \\
\text { communities in tourism development and promotion } \\
\text { - Enhance cooperation with development partners } \\
\text { to mobilize technical assistance and financing for } \\
\text { sustainable tourism } \\
\text { - Ensure tourism is socially, environmentally, and } \\
\text { economically sustainable }\end{array}$ & $\begin{array}{l}\text { Specific targets } \\
\text { have not been set }\end{array}$ \\
\hline
\end{tabular}

CLMV = Cambodia, the Lao People's Democratic Republic, Myanmar, and Viet Nam; Lao PDR = Lao People's Democratic Republic.

Sources: National tourism organizations; Third Meeting of the CLMV Tourism Ministers. 2015. Nay Pyi Taw. 


\section{Table 17: Tourism Advisory Boards and Industry Associations}

\begin{tabular}{|c|c|c|}
\hline Entity & Mission and Objectives & Membership \\
\hline $\begin{array}{l}\text { Cambodia Hotel } \\
\text { Association }\end{array}$ & $\begin{array}{l}\text { To be the collective voice of Cambodia's hotel industry } \\
\text { promoting advocacy, networking, and marketing and } \\
\text { promotion } \\
\text { Work with government to resolve issues affecting the } \\
\text { hotel business and tourism in general } \\
\text { Encourage best practices through workshops, forums, } \\
\text { and training opportunities to develop and strengthen the } \\
\text { hotel industry in Cambodia }\end{array}$ & $\begin{array}{l}94 \text { mainly larger hotels and } \\
\text { hospitality-related enterprises }\end{array}$ \\
\hline $\begin{array}{l}\text { Cambodia } \\
\text { Association of } \\
\text { Travel Agents }\end{array}$ & $\begin{array}{l}\text { - Focused advocacy for tourism growth, strategic tourism } \\
\text { services, and national and international networking } \\
\text { - Sustainable economic growth for the long-term benefit } \\
\text { of Cambodian tourism and people }\end{array}$ & $\begin{array}{l}197 \text { tour operators and } \\
\text { travel agents }\end{array}$ \\
\hline $\begin{array}{l}\text { Cambodian } \\
\text { Tourism Marketing } \\
\text { \& Promotion Board }\end{array}$ & $\begin{array}{l}\text { Legal mandate to be formed as a public-private } \\
\text { partnership. A subdecree defining the organization and } \\
\text { functioning of the board is being prepared and approval } \\
\text { is expected in } 2016\end{array}$ & --- \\
\hline $\begin{array}{l}\text { Lao Hotel and } \\
\text { Restaurant } \\
\text { Association }\end{array}$ & $\begin{array}{l}\text { - Represent and promote its members' interests nationally } \\
\text { and internationally } \\
\text { - Analyze market segments and disseminate information } \\
\text { - Organize forums and training courses to increase service } \\
\text { quality and competitiveness } \\
\text { - Participate in the formulation of industry standards }\end{array}$ & About 80 hotels and restaurants \\
\hline $\begin{array}{l}\text { Lao Tour Operators } \\
\text { Association }\end{array}$ & $\begin{array}{l}\text { - Promote the Lao PDR as a quality tourism destination in } \\
\text { all trade markets worldwide } \\
\text { - Ensure that the highest standards of service are offered } \\
\text { by the Lao PDR travel industry } \\
\text { - Enhance business ethics of the travel profession } \\
\text { - Encourage development of a sustainable tourism industry } \\
\text { in the Lao PDR } \\
\text { - Support and expand international affiliations }\end{array}$ & $\begin{array}{l}55 \text { tour operators/agents that } \\
\text { handle more than } 60 \% \text { of } \\
\text { inbound tourists who book an } \\
\text { organized tour }\end{array}$ \\
\hline $\begin{array}{l}\text { Myanmar Tourism } \\
\text { Federation }\end{array}$ & $\begin{array}{l}\text { Represent the private sector to promote Myanmar } \\
\text { as a responsible world-class destination benefiting } \\
\text { communities, culture, and environment } \\
\text { Cochair meetings of the Myanmar Tourism Sector } \\
\text { Working Group, together with the Ministry of Hotels } \\
\text { and Tourism }\end{array}$ & $\begin{array}{l}11 \text { industry associations, } \\
\text { representing hotels, travel } \\
\text { agents, hospitality professionals, } \\
\text { restaurants, tourism transport, } \\
\text { souvenir shops, tour operators, } \\
\text { tourist health care, tour guides, } \\
\text { tourism human resources } \\
\text { development, and tourism } \\
\text { marketing }\end{array}$ \\
\hline $\begin{array}{l}\text { Viet Nam Tourism } \\
\text { Advisory Board }\end{array}$ & $\begin{array}{l}\text { Promote and lobby for the development of trade, } \\
\text { commerce, and investment in Viet Nam's travel and } \\
\text { tourism industry } \\
\text { - Participate in the development of tourism public policy } \\
\text { through an open and honest dialogue between private } \\
\text { companies, state-owned enterprises, and the government } \\
\text { - Provide a forum for industry leaders and public officials } \\
\text { to identify and discuss commercial, environmental, } \\
\text { educational, and sustainable industry goals } \\
\text { - Assist in the national branding campaign and a sustainable } \\
\text { destination marketing program }\end{array}$ & $\begin{array}{l}\text { Hotels, travel agencies, } \\
\text { transportation businesses, } \\
\text { chairpersons of tourism } \\
\text { industry associations, leaders } \\
\text { of training institutions, senior } \\
\text { public officials, representatives } \\
\text { from the Viet Nam Chamber of } \\
\text { Commerce and Industry, and } \\
\text { foreign chambers of commerce }\end{array}$ \\
\hline
\end{tabular}

--- = data not available, Lao PDR = Lao People's Democratic Republic.

Source: National tourism organization and industry association websites. 
65. Given the lack of official reports on the status of strategy implementation, progress in Cambodia and Viet Nam is assessed by comparing World Economic Forum Travel and Tourism Competitiveness Index (TTCl) rankings for 2013 and 2015 as a proxy. Since the Lao PDR and Myanmar were not included in the index until 2015, the current category rankings for key indicators such as the business-enabling environment, human resources, and infrastructure are measured against benchmarks for ASEAN and South Asia.

66. Cambodia's global TTCl ranking improved slightly, from 106 in 2013 to 105 in 2015. Efforts to improve tourist safety and security, continued prioritization of travel and tourism, international openness, health and hygiene in major tourist destinations, and ICT readiness saw the best progress. While improving, major constraints continue to be a weak business-enabling environment, shortages of skilled tourism workers, environmental management, and insufficient protection of natural and cultural heritage assets. Scores for infrastructure remain well below regional benchmarks, due to the shortage of airports and convenient ground/sea access beyond the major gateways, as well as the lack of paved roads linking urban centers with rural attractions.

67. The Lao PDR ranked 96th out of 141 economies assessed in the $2015 \mathrm{TTCl}$. Category rankings that match or outperform regional benchmarks include safety and security, prioritization of travel and tourism, price competitiveness, international openness, and environmental sustainability. Although local entrepreneurs find it relatively simple to open micro and small enterprises, both national and international investors face cumbersome procedures to start and operate medium-sized and large enterprises. Efforts to improve human resources and service quality received a boost in 2014 with the establishment of the Lao National Institute for Tourism and Hospitality and its innovative Passport to Success vocational training program. Air, ground, and port infrastructure all scored below regional benchmarks. Health and hygiene were also rated low, due to insufficient clean water supply and sanitation, which is compounded by a lack of international-standard medical facilities. The government's investment program for tourism (2011-2015) cost \$118 million, with the majority earmarked for transport infrastructure.

68. Myanmar ranks lowest (134) among CLMV in the $2015 \mathrm{TTCl}$. Even so, it was the fastestgrowing tourist destination in ASEAN from 2013 to 2015, and recent positive changes to the business environment, international openness, and prioritization of travel and tourism are not reflected in the ranking. Areas that substantially trail regional benchmarks are health and hygiene, human resources, ICT readiness, price competitiveness, ground and port infrastructure, and tourist service infrastructure. Recent Myanmar Tourism Sector Working Group meetings confirm that implementation of the Myanmar Tourism Master Plan is on track. Priority projects to build human resources and strengthen service quality, strengthen destination planning and management, develop quality tourism products and services, and support internal and external marketing have garnered the most support. Programs involving infrastructure to facilitate access to tourist attractions and upgrade environmental services are progressing more slowly because of the time required to prepare proper feasibility studies and to secure financing. The master plan includes seven priority infrastructure projects, with an estimated total cost of $\$ 251$ million.

69. Viet Nam's global TTCl ranking advanced from 80 in 2013 to 75 in 2015. Viet Nam outperformed regional benchmarks for safety and security, health and hygiene, human resources, ICT readiness, and price competitiveness. There were considerable improvements in the businessenabling environment. Viet Nam's score for international openness dropped below the regional benchmark in 2015 and is currently among the lowest in ASEAN. In response, the government began allowing visa-free access to visitors from France, Germany, Italy, Spain, and the United Kingdom in July 2015 and is considering lengthening the list of countries eligible for tourist visa exemption. An electronic visa system is also being developed for launch in early 2017. Although Viet Nam has considerably improved its gateway air transport infrastructure, tourist service infrastructure, and the 
national road network, it lags behind regional benchmarks in all categories. The emphasis on lastmile access infrastructure and better sanitary conditions is reflected in the Ministry of Culture, Sports and Tourism's assessment of its budgetary expenditure on infrastructure from 2001 to 2010, which saw $90 \%$ of total spending devoted to finance access improvements, $6 \%$ to drainage and sanitation, $2 \%$ to water supply, and $2 \%$ to power supply. ${ }^{51}$

\section{B. ADB Tourism Support Program and Experience}

70. ADB provided $\$ 167.24$ million in concessional loans, grants, and technical assistance to support tourism-related public infrastructure and capacity building in CLMV from 2003 to 2014 (Table 18). The recently approved GMS Tourism Infrastructure for Inclusive Growth project (2014) accounts for $\$ 108$ million of the total..$^{52}$ In addition, ADB administered the Japan Fund for Poverty Reduction's \$1.9 million Improving Market Access for the Poor in Central Cambodia investment grant and a $\$ 225,000$ grant from the Government of Norway to prepare Myanmar's first tourism master plan..$^{53}$

71. ADB's tourism support program has consistently aligned with sustainable economic growth objectives and core areas of intervention for inclusive social development. ${ }^{54}$ The first and second GMS tourism projects were designed to improve access infrastructure and environmental services in tourist destinations and strengthen the capacity of government and the private sector to boost regional tourism investment that creates jobs for the poor. These objectives remain consistent with the strategic focus of ADB Strategy 2020 and its midterm review as well as pillar 1 and pillar 2 of ADB's Regional Cooperation and Integration Strategy. ${ }^{55}$

72. The ongoing GMS Tourism Infrastructure for Inclusive Growth project in Cambodia, the Lao PDR, and Viet Nam builds on the successful experience of previous subregional tourism projects. It has four outputs: (i) improved last-mile tourism access infrastructure, (ii) improved environmental services in cross-border tourism centers, (iii) strengthened institutional capacity to promote inclusive tourism growth, and (iv) effective project implementation and knowledge management. The project's emphasis on improving connectivity between urban and rural areas, strengthening market linkages, and creating jobs for unskilled and semiskilled workers living in underdeveloped segments of GMS corridors are closely aligned with the overarching poverty reduction and inclusive growth objectives of ADB country partnership strategies for Cambodia, the Lao PDR, and Viet Nam. ${ }^{56}$

51 Ministry of Culture, Sports and Tourism. 2012. Strategy for Tourism Development in Viet Nam to 2020, Vision to 2030. Ha Noi.

52 ADB. 2014. Report and Recommendation of the President to the Board of Directors on Proposed Loan to the Kingdom of Cambodia for Greater Mekong Subregion: Tourism Infrastructure for Inclusive Growth Project. Manila; ADB. 2014. Report and Recommendation of the President to the Board of Directors on Proposed Loan to the Lao People's Democratic Republic for Greater Mekong Subregion: Tourism Infrastructure for Inclusive Growth Project. Manila; ADB. 2014. Report and Recommendation of the President to the Board of Directors on Proposed Loan to the Socialist Republic of Viet Nam for Greater Mekong Subregion: Tourism Infrastructure for Inclusive Growth Project. Manila.

53 ADB. 2011. Grant Assistance Report. Proposed Grant Assistance Cambodia: Improving Market Access for the Poor in Central Cambodia. Manila; ADB. 2012. Technical Assistance 8136. Myanmar Tourism Master Plan. Manila.

54 ADB. 2001. Moving the Poverty Reduction Agenda Forward in Asia and the Pacific: The Long-Term Strategic Framework of the Asian Development Bank (2001-2015). Manila.

55 ADB. 2008. Strategy 2020: The Long-Term Strategic Framework of the Asian Development Bank 2008-2020. Manila. ADB. 2006. Regional Cooperation and Integration Strategy. Manila.

56 ADB. 2014. Country Partnership Strategy: Cambodia, 2014-2018. Manila; ADB. 2011. Country Partnership Strategy: Lao People's Democratic Republic, 2012-2016. Manila; ADB. 2012. Country Partnership Strategy: Viet Nam, 2012-2015. Manila. 


\section{Table 18: ADB Tourism Support: Cambodia, the Lao People's Democratic Republic, Myanmar, and Viet Nam}

\begin{tabular}{|c|c|c|c|c|}
\hline Loan/Grant/Technical Assistance & Years $^{a}$ & $\begin{array}{l}\text { Amount } \\
\text { (\$ million) }\end{array}$ & Objectives & Rating \\
\hline $\begin{array}{l}\text { Greater Mekong Subregion (GMS) } \\
\text { Mekong Tourism Development } \\
\text { Project: L1969-CAM (SF); } \\
\text { L1970-LAO (SF); L1971-VIE (SF) }\end{array}$ & $2003-2010$ & 37.31 & $\begin{array}{l}\text { Improve access and } \\
\text { environmental infrastructure, } \\
\text { promote pro-poor tourism, } \\
\text { and develop regional tourism } \\
\text { standards. }\end{array}$ & Successful \\
\hline $\begin{array}{l}\text { GMS Tourism Sector Strategy: } \\
\text { R-CDTA } 6179\end{array}$ & 2004-2006 & 0.80 & $\begin{array}{l}\text { Prepare a 10-year } \\
\text { GMS tourism strategy } \\
\text { to promote sustainable } \\
\text { tourism development that } \\
\text { reduces poverty. }\end{array}$ & $\begin{array}{l}\text { Highly } \\
\text { Successful }\end{array}$ \\
\hline $\begin{array}{l}\text { Preparing the GMS Sustainable } \\
\text { Tourism Development Project: } \\
\text { R-PPTA } 6279\end{array}$ & $2006-2008$ & 0.90 & $\begin{array}{l}\text { Prepare ensuing investment } \\
\text { project. }\end{array}$ & Successful \\
\hline $\begin{array}{l}\text { GMS Sustainable Tourism } \\
\text { Development Project: } \\
\text { L2457-VIE (special funds [SF]); } \\
\text { G0117-LAO (SF) }\end{array}$ & $2008-2014$ & 18.80 & $\begin{array}{l}\text { Sustainable tourism } \\
\text { development that creates } \\
\text { livelihood opportunities } \\
\text { for the poor. }\end{array}$ & Successful ${ }^{b}$ \\
\hline $\begin{array}{l}\text { Improving Market Access for } \\
\text { the Poor in Central Cambodia: } \\
\text { Japan Fund for Poverty Reduction } \\
\text { 9156-CAM }\end{array}$ & 2011-2014 & 1.93 & $\begin{array}{l}\text { Increase income and } \\
\text { local employment for } \\
\text { poor households. }\end{array}$ & Successful \\
\hline $\begin{array}{l}\text { Myanmar Tourism Master Plan: } \\
\text { PATA 8136-MYA }\end{array}$ & $2012-2013$ & 0.23 & $\begin{array}{l}\text { Prepare Myanmar tourism } \\
\text { master plan, emphasizing } \\
\text { employment and income } \\
\text { generation, equitable benefit } \\
\text { distribution. }\end{array}$ & $\begin{array}{l}\text { Highly } \\
\text { Successful }\end{array}$ \\
\hline $\begin{array}{l}\text { Preparing the GMS Tourism } \\
\text { Infrastructure for Inclusive Growth } \\
\text { Project: R-PPTA } 8233\end{array}$ & 2012-2014 & 1.20 & $\begin{array}{l}\text { Prepare ensuing } \\
\text { investment project. }\end{array}$ & Successful \\
\hline $\begin{array}{l}\text { Strengthening the Mekong Tourism } \\
\text { Coordinating Office: R-CDTA } 8156\end{array}$ & $2012-2016$ & 0.23 & $\begin{array}{l}\text { Strengthen the institutional } \\
\text { framework for GMS tourism } \\
\text { cooperation. }\end{array}$ & $\begin{array}{l}\text { Project } \\
\text { ongoing }\end{array}$ \\
\hline $\begin{array}{l}\text { GMS Tourism Infrastructure for } \\
\text { Inclusive Growth Project: L3194- } \\
\text { CAM (SF); L3156-LAO (SF); } \\
\text { L3165-VIE (SF) }\end{array}$ & 2014-2019 & 108.00 & $\begin{array}{l}\text { Increase tourism receipts } \\
\text { and employment in } \\
\text { underdeveloped segments of } \\
\text { the GMS economic corridors. }\end{array}$ & $\begin{array}{l}\text { Project } \\
\text { ongoing }\end{array}$ \\
\hline $\begin{array}{l}\text { Preparing the Second GMS } \\
\text { Tourism Infrastructure for Inclusive } \\
\text { Growth project: R-PPTA } 9090\end{array}$ & 2016-2019 & 1.50 & $\begin{array}{l}\text { Prepare ensuing } \\
\text { investment project. }\end{array}$ & $\begin{array}{l}\text { Project } \\
\text { ongoing }\end{array}$ \\
\hline \multicolumn{5}{|l|}{$\begin{array}{l}\text { GMS = Greater Mekong Subregion. } \\
\text { a Years denotes implementation period. }\end{array}$} \\
\hline
\end{tabular}


73. In addition to capacity-building components of loan and grant projects, ADB's GMS Phnom Penh Plan for Development Management organized an annual tourism management learning program for midlevel officials from 2006 to 2014. The two-week course introduced 178 public tourism managers to perspectives, tools, frameworks, and key concepts on tourism and strengthened their competencies to develop and implement strategic tourism interventions. ${ }^{57}$ Many course graduates are now senior officials who capably manage tourism development in their respective countries. Likewise, the GMS Core Environment Program has provided modest support for community-based ecotourism activities in the Lao PDR and Cambodia and produced a strategic environmental assessment of Cambodia's tourism sector. ${ }^{58}$ In 2012, the GMS Core Environment Program also prepared a strategic environmental assessment of tourism sector strategies in the Golden Quadrangle, covering Yunnan Province, PRC; northeast Myanmar; northwest Lao PDR; and northern Thailand. The assessments demonstrate how to mainstream environmental concerns in tourism planning and facilitate cooperation among line ministries, the private sector, and development partners.

\section{Other Development Partner Support}

74. The main sources of lending and grant assistance for tourism in CLMV are Agence Française de Développement (AFD), the European Union, Deutsche Gesellschaft für Internationale Zusammenarbeit, the Japan International Cooperation Agency, KfW, Government of the Grand Duchy of Luxembourg, the New Zealand International Development Agency, the Swiss Agency for Development and Cooperation, and the Swiss State Secretariat for Economic Affairs. Lending to the private sector for hotel and resort development is mainly handled by the World Bank Group's International Finance Corporation. Agencies that mainly provide technical assistance include the Darwin Initiative, the Hanns Seidel Foundation, the International Centre for Integrated Mountain Development, the International Labour Organization, the Netherlands Development Organization, SwissContact, the United Nations Development Programme, UNESCO, the UNWTO, the Wildlife Conservation Society, and the World Wildlife Fund. The United Nations Economic and Social Commission for Asia and the Pacific, together with Pacific Asia Travel Association, supported GMS Tourism Working Group meetings and the Mekong Tourism Forum from 1995 to 2006. Costs for organizing these events are now shouldered by the GMS countries themselves.

75. Support to improve the business-enabling environment for tourism in the Lao PDR is provided by Swiss Contact and the New Zealand International Development Agency, with focus on capacity building for destination planning and management. The Hanns Seidel Foundation helped Myanmar develop its Responsible Tourism Policy and Policy on Community Involvement in Tourism. The International Centre for Integrated Mountain Development assisted Myanmar to prepare its recently approved Ecotourism Policy and Management Strategy. In the mid-2000s, the UNWTO was active in Cambodia, the Lao PDR, and Viet Nam, helping these countries to prepare and promulgate tourism laws, develop tourism master plans for flagship tourism destinations, and improve destination marketing.

76. Luxembourg, the Swiss Agency for Development and Cooperation, and the European Union mainly support human resource development, concentrating on tourism education and vocational training in the Lao PDR, Myanmar, and Viet Nam. In Cambodia, AFD is supporting establishment of the National School for Tourism Professionals in Phnom Penh, which complements the private sector initiative Ecole d'Hotellerie et de Tourisme Paul Dubrule in Siem Reap.

\footnotetext{
57 ADB. 2014. The Phnom Penh Plan for Development Management a Retrospective. Manila.

58 ADB. 2009. Strategic Environmental Assessment of the Tourism Sector in Cambodia. Manila.
} 
77. Financing for transport infrastructure and municipal services is mainly sourced from AFD, the Japan International Cooperation Agency, KfW, the Export-Import Bank of Korea, the Government of Australia, the Government of the People's Republic of China, the Swedish International Development Cooperation Agency, and the World Bank Group.

78. Development partners also help CLMV to protect cultural and natural tourism assets. In the Lao PDR, the Wildlife Conservation Society has pioneered an innovative program that provides incentive payments to communities when tourists spot wildlife in designated conservation areas. UNESCO provides technical assistance to improve heritage management and safeguard world heritage properties. Efforts to combat the sexual exploitation of children are led by national law enforcement agencies with the support of World Vision, ECPAT International, and the United Nations Office on Drugs and Crime.

79. Several agencies support projects to strengthen market linkages between tourism and other sectors. These include the European Union, Deutsche Gesellschaft für Internationale Zusammenarbeit, and the International Trade Center. The focus is on helping micro, small, and medium-sized enterprises to link into tourism supply chains and enhance product competitiveness. There also are many social enterprises active in this area.

80. Development partner support at the subregional level is coordinated by various ASEAN tourism working groups and the GMS Tourism Working Group under the direction of senior officials representing member country national tourism organizations. For ASEAN, these include a Tourism Competitiveness Working Group, Sustainable and Inclusive Tourism Working Group, Tourism Resourcing and Monitoring and Evaluation Committee, and Tourism Professional Monitoring Committee. The GMS Tourism Working Group meets twice per year to direct GMS Tourism Sector Strategy implementation, share knowledge and good practices for sustainable tourism development, and coordinate joint marketing activities. Appendix 2 presents a comprehensive list of recent development partner assistance.

\section{ADB Experience and Self-Evaluation}

81. ADB's tourism assistance is rated successful or highly successful, considering its relevance to national and regional priorities, its effective and efficient achievement of project/technical assistance outputs and outcomes, and its sustainability. ${ }^{59}$ The 2009 GMS Tourism Sector Assistance Program Evaluation found that ADB's tourism support program is an important GMS initiative that substantially contributes to the strategic directions, planning, and collective actions of the GMS countries. Overall, the program evaluation rates ADB assistance to the GMS tourism sector successful. ${ }^{60}$ ADB is considered an effective neutral broker in light of its ability to bring together diverse stakeholders and build consensus on various issues, as shown by GMS countries' joint endorsement of the GMS Tourism Sector Strategy, establishment of the Mekong Tourism Coordination Office, and endorsement of the GMS Tourism Marketing Strategy and Action Plan. ADB has actively participated in GMS Tourism Working Group meetings since 1995. ${ }^{61}$

59 ADB. 2006. Technical Assistance Completion Report: Greater Mekong Subregion Tourism Sector Strategy. Manila; ADB. 2010. Completion Report: Greater Mekong Subregion Mekong Tourism Development Project. Manila; ADB. 2013. Technical Assistance Completion Report: Myanmar Tourism Master Plan. Manila.

60 ADB. 2009. Sector Assistance Program Evaluation: Tourism Sector in the Greater Mekong Subregion. Manila.

61 As of January 2016, the GMS Tourism Working Group has met 36 times. The Mekong Tourism Coordinating Office was established in 2006. It functions as the GMS Tourism Working Group Secretariat. 
82. On the other hand, the program evaluation recommends that ADB's subregional tourism support could further enhance synergies with national and subregional projects involving infrastructure, trade facilitation, environmental protection, and cross-border agreements. Although the evaluation highlights the need to support policy dialogue that could reduce barriers to subregional travel, much progress has been made in this area since 2009.

83. Sector assistance program evaluation recommendations to implement cross-border transport agreements that simplify arrangements for moving private vehicles across borders remain valid, given the increasing rates of passenger vehicle ownership. The need to better package sustainable tourism products and destinations into multicountry tour circuits that encourage tourists to visit more than one country also remains valid, as is the need for infrastructure investments and service quality improvements in destinations situated along multicountry circuits.

84. Political economy concerns. Several factors suggest that government and the private sector will continue to strongly support tourism growth. CLMV have prioritized quality and inclusive tourism growth in national socioeconomic development plans and have committed to promoting cross-border tourism as signatories to the ASEAN Economic Community Blueprint and the GMS Economic Cooperation Program Strategic Framework 2012-2022.62 The blueprint directs ASEAN member countries to remove substantially all restrictions on trade in services for four mutually reinforcing priority sectors: air transport, e-commerce, health care, and tourism. The GMS Strategic Framework prioritizes tourism development and removal of nonphysical barriers to cross-border transport to facilitate trade, tourism, and investment. These policies will have positive effects on inclusive growth because of tourism's ability to generate jobs and income in lagging areas and to help governments achieve poverty reduction targets. As tourism in the GMS and ASEAN becomes increasingly intraregional, with interlinked supply chains, tourism will generate more mutual economic benefits and shared prosperity. High-level political support for environmental and social sustainability prominently features in CLMV's tourism development agendas and the United Nations Sustainable Development Goals. ${ }^{63}$

85. Lessons. Key lessons from the GMS Mekong Tourism Development Project and the GMS Sustainable Tourism Development Project highlight the need to (i) analyze tourism demand in project areas to guide the selection of infrastructure investments; (ii) improve cross-sector coordination and build synergies with other ADB assistance; (iii) provide capacity building for project management early in the project cycle; (iv) design larger climate-resilient projects with well-defined infrastructure and capacity-building components, without spreading resources over a wide geographic area; ( $v$ ) strengthen mechanisms to sustainably finance operations and maintenance of civil works; and (vi) promote tourism-related private enterprise development alongside infrastructure to expand income-generating opportunities for local residents. Other lessons from past operations in Southeast Asia and South Asia, and better practices to promote more inclusive and balanced tourism growth, are as follows:

(i) ADB should focus its assistance on larger investments with public-good elements (roads, solid waste and wastewater management, other utilities, and human resources to manage tourism assets) that are too big for individual investors and that have positive catalytic effects for downstream private investment.

\footnotetext{
62 ASEAN Secretariat. 2008. ASEAN Economic Community Blueprint. Jakarta; ADB. 2011. Greater Mekong Subregion Economic Cooperation Program Strategic Framework, 2012-2022. Manila.

63 United Nations. 2015. Transforming Our World: The 2030 Agenda for Sustainable Development. New York. Target 8.9 is to devise and implement policies to promote sustainable tourism that creates jobs and promotes local culture and products.
} 
(ii) When project design entails many implementing agencies, the role of a centralized project coordination unit staffed with counterparts skilled in procurement, financial management, and other aspects of project administration takes on added importance.

(iii) Capability enhancement for implementing agencies, based on thorough institutional assessments, should be carried out well in advance of infrastructure procurement and construction.

(iv) There is an ongoing need to build capacity to facilitate better enforcement of laws and regulations in tourism destinations, such as penalties for illegal sewage and solid waste disposal.

(v) Ecotourism and community-based tourism can be effective tools to promote nature conservation and generate income and employment for local residents. However, development partner assistance for such ventures should be subject to rigorous financial and market feasibility assessments. Experience shows that it is difficult to establish community lodges as viable enterprises in many areas.

(vi) Project-supported grassroots community enterprise development requires significant resources, which limits the scale at which such development can be replicated.

86. Implications for ADB's forward strategy. Given significant infrastructure financing gaps and the activities of other development partners-particularly support for tourism vocational education and training-ADB should continue to focus its assistance on complementary investments in last-mile transport infrastructure; expanding environmental services; micro, small, and mediumsized enterprise promotion; capacity building for public officials; and support for CLMV to develop and implement regional tourism standards. Such investments are necessary to create favorable conditions for private sector expansion into secondary tourist destinations, strengthen market linkages, and improve environmental sustainability.

\section{E. ADB Sector Forward Strategy}

87. ADB's involvement in the tourism sector will continue, given its successful experience in financing multisector projects with regional public-good characteristics and substantial positive development impacts. These include job creation for the poor and improved environmental performance in tourism destinations. ADB support will remain focused on improving last-mile transport infrastructure, sanitation, water supply, and other public infrastructure in secondary tourist destinations to catalyze downstream private investment and job creation, boost trade in services, and improve environmental sustainability. The focus on infrastructure is consistent with ADB Strategy 2020 and its midterm review, ADB's Regional Cooperation and Integration Strategy, the ASEAN Tourism Strategic Plan, the GMS Strategic Framework 2012-2022, and CLMV's tourism development plans and policies (Appendix 3).

88. Capacity building for public officials will focus on increasing their capabilities to better manage public tourism assets, facilitate private investment, and establish systems and procedures to implement regional tourism standards. ADB will continue to promote micro, small, and medium-sized enterprise development as a subcomponent of tourism projects and through operations that support industry and trade. The proposed pipeline of projects and technical assistance will maximize synergies with other ADB investments in the transport, urban, and social sectors. ADB will continue to serve as regional advisor to the GMS Tourism Working Group and to support subregional efforts to prepare a new GMS Tourism Sector Strategy for 2016-2025. ADB also will support GMS efforts to market the Mekong region as a single tourist destination and improve tourism knowledge management. 
89. Lending and nonlending program and resource needs. The GMS Regional Investment Framework Implementation Plan 2014-2018 identifies a list of 18 tourism projects with an estimated cost of $\$ 740.7$ million. Among these, three investment projects estimated to cost $\$ 450$ million and three technical assistance projects estimated to cost $\$ 2.4$ million have been selected as high-priority projects by the GMS Tourism Working Group. ADB approved financing for the first GMS Tourism Infrastructure for Inclusive Growth project in 2014, covering Cambodia (\$18 million), the Lao PDR ( $\$ 40$ million), and Viet Nam ( $\$ 50$ million). Resource requirements for the proposed Second GMS Tourism Infrastructure for Inclusive Growth project are shown in Table 19 and are reflected in ADB's Regional Cooperation and Integration Pipeline for Southeast Asia 2015-2017. ${ }^{64}$

\section{Table 19: Indicative Tourism Support Program}

\begin{tabular}{|c|c|c|c|c|}
\hline Project Name & Year & Country Coverage & Assistance Type & $\begin{array}{l}\text { Amount } \\
\text { (\$ million) }\end{array}$ \\
\hline \multicolumn{5}{|l|}{ Nonlending Products } \\
\hline $\begin{array}{l}\text { Preparing the New GMS Tourism } \\
\text { Sector Strategy 2016-2025 }\end{array}$ & 2016 & All GMS countries & $\begin{array}{l}\text { Regional Policy and Advisory } \\
\text { Technical Assistance }\end{array}$ & 0.8 \\
\hline $\begin{array}{l}\text { Preparing the Second GMS } \\
\text { Tourism Infrastructure for } \\
\text { Inclusive Growth Project }\end{array}$ & 2016 & CLMV & $\begin{array}{l}\text { Regional Project Preparatory } \\
\text { Technical Assistance }\end{array}$ & 1.5 \\
\hline \multicolumn{5}{|l|}{ Lending Products } \\
\hline $\begin{array}{l}\text { Second GMS Tourism } \\
\text { Infrastructure for } \\
\text { Inclusive Growth Project }\end{array}$ & 2018 & CLMV & $\begin{array}{l}\text { Concessional Ordinary } \\
\text { Capital Resources }\end{array}$ & 155 \\
\hline
\end{tabular}

CLMV = Cambodia, the Lao People's Democratic Republic, Myanmar, and Viet Nam; GMS = Greater Mekong Subregion; Lao PDR = Lao People's Democratic Republic.

Source: Asian Development Bank estimates.

90. Given that the formulation of an updated GMS Tourism Sector Strategy in 2016 will involve identification of priority infrastructure and capacity-building investments in all GMS countries, the proposed regional policy and advisory technical assistance Preparing the New GMS Tourism Sector Strategy 2016-2026 was merged with the regional project preparatory technical assistance Preparing the Second GMS Tourism Infrastructure for Inclusive Growth project. This will ensure appropriate sequencing of investments and increased operational efficiency. The ensuing Second GMS Tourism Infrastructure for Inclusive Growth Project will build on experience and lessons to boost tourism employment and expenditure in secondary destinations by improving urban-rural connectivity, expanding the quality and coverage of environmental services, and strengthening capacity to sustainably manage tourism growth.

91. Assumptions and risks. Key assumptions for the proposed tourism support program are that governments in Southeast Asia will continue to support expansion of the travel and tourism industry and reforms that open their economies. Challenges related to the coordination of cross-border initiatives due to the different levels of development and capacity across the region are considered manageable and will be addressed by incorporating suitable coordination mechanisms and training in program design. Although continued growth in international and domestic tourism could be affected by natural disasters, political events, or economic downturns, tourism has proven to be highly resilient when faced with these situations, and is expected to remain so.

${ }^{64}$ ADB. 2015. Regional Cooperation and Integration Pipeline for Southeast Asia 2015-2017. Manila. 


\section{Appendix 1 \\ Problem Tree for Tourism in Cambodia, the Lao People's Democratic Republic, Myanmar, and Viet Nam}

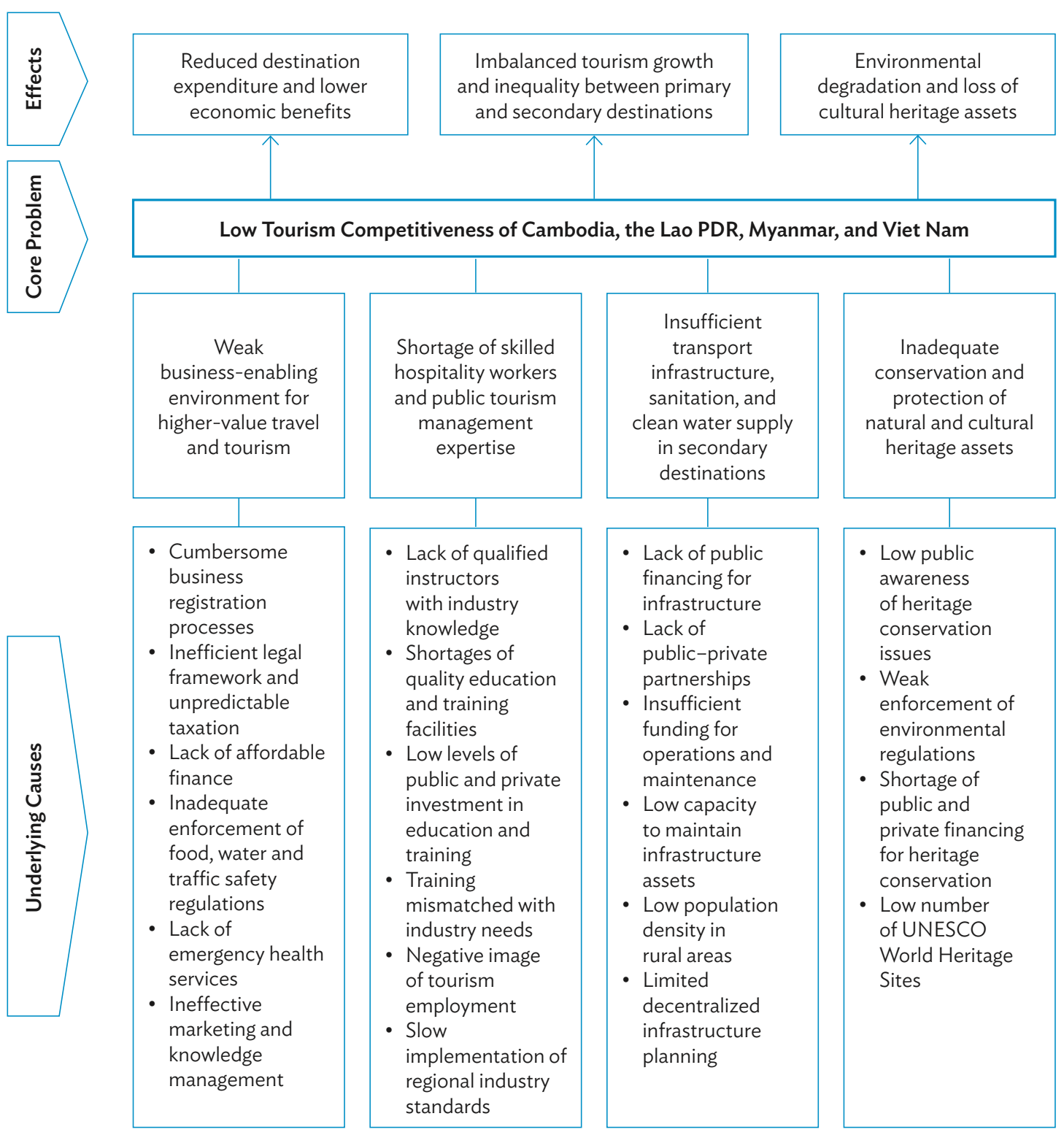

Lao PDR = Lao People's Democratic Republic; UNESCO = United Nations Educational, Scientific and Cultural Organization.

Note: The World Economic Forum defines tourism competitiveness as the set of factors and policies that enable the sustainable development of the travel and tourism sector, comprising four subindexes: (i) enabling environment, (ii) travel and tourism policy and enabling conditions, (iii) infrastructure, and (iv) natural and cultural resources. 


\section{Appendix 2 \\ Development Partner Assistance: \\ Cambodia, the Lao People's Democratic Republic, Myanmar, and Viet Nam}

\begin{tabular}{|c|c|c|c|}
\hline Development Partner & Project/Technical Assistance & Duration & $\begin{array}{l}\text { Cost } \\
\text { Estimate } \\
\text { (\$ million) }\end{array}$ \\
\hline \multicolumn{4}{|c|}{ Cambodia } \\
\hline$A D B$ & $\begin{array}{l}\text { GMS Tourism Infrastructure for } \\
\text { Inclusive Growth Project }\end{array}$ & 2014-2019 & 18.0 \\
\hline ADB-JFPR & $\begin{array}{l}\text { Improving Market Access for the Poor } \\
\text { in Central Cambodia }\end{array}$ & 2011-2015 & 1.9 \\
\hline UNWTO/SNV & Mekong Discovery Trail Project & 2007-2012 & --- \\
\hline$A D B$ & GMS Mekong Tourism Development Project & $2003-2010$ & 16.8 \\
\hline AFD & $\begin{array}{l}\text { Strengthening the Capacity of Public and } \\
\text { Private Stakeholders and Improving the } \\
\text { Tourism Sector Development Strategy }\end{array}$ & 2016-2018 & 1.7 \\
\hline AFD & Tourism Infrastructure Development & $2015-2018$ & 12.1 \\
\hline European Union & $\begin{array}{l}\text { Raising Public Awareness of Climate Change } \\
\text { in Tourism Sector }\end{array}$ & & 0.2 \\
\hline \multicolumn{4}{|c|}{ Lao PDR } \\
\hline Luxembourg and SDC & Skills for Tourism & $2016-2020$ & 17.0 \\
\hline NZAID & Lao Tourism Support Activity & 2015-2019 & 3.1 \\
\hline$A D B$ & $\begin{array}{l}\text { GMS Tourism Infrastructure for Inclusive } \\
\text { Growth Project }\end{array}$ & 2015-2019 & 40.0 \\
\hline GIZ & $\begin{array}{l}\text { Integrated Nature Conservation and Sustainable } \\
\text { Resource Management in the Hin Nam No Region }\end{array}$ & $2013-2018$ & --- \\
\hline Swiss Contact and SDC & Champassak Tourism Business Promotion Project & $2013-2016$ & 2.2 \\
\hline SECO, ILO & $\begin{array}{l}\text { Enhancing Sustainable Tourism, Cleaner Production } \\
\text { and Export Capacity in Lao PDR }\end{array}$ & 2011-2016 & 4.0 \\
\hline NZAID & $\begin{array}{l}\text { Community-Based Tourism for Sustainable } \\
\text { Economic Development }\end{array}$ & 2011-2014 & 3.5 \\
\hline JICA & $\begin{array}{l}\text { Laos Pilot Program for Narrowing the } \\
\text { Development Gap towards ASEAN Integration }\end{array}$ & 2010-2015 & --- \\
\hline Luxembourg & $\begin{array}{l}\text { Strengthening Human Resources in the } \\
\text { Tourism and Hospitality Industry }\end{array}$ & 2009-2016 & 9.8 \\
\hline
\end{tabular}


Continued

\begin{tabular}{|c|c|c|c|}
\hline Development Partner & Project/Technical Assistance & Duration & $\begin{array}{l}\text { Cost } \\
\text { Estimate } \\
(\$ \text { million })\end{array}$ \\
\hline ADB & GMS Sustainable Tourism Development Project & 2008-2014 & 10.0 \\
\hline JICA & Facilitation of Tourism on the East-West Corridor & $2006-2011$ & 1.1 \\
\hline UNESCO, NZAID & $\begin{array}{l}\text { Fighting Poverty at the Plain of Jars: UXO } \\
\text { Clearance, Pro-poor Tourism and Sustainable } \\
\text { Resource Management in Xieng Khouang, Lao PDR }\end{array}$ & $2006-2010$ & 1.1 \\
\hline WWF & Xe Pian Ecotourism Project & 2006-2009 & 0.4 \\
\hline ADB & GMS Mekong Tourism Development Project & $2003-2008$ & 12.6 \\
\hline NZAID & Nam Ha Ecotourism Project & 1999-2006 & 0.9 \\
\hline \multicolumn{4}{|c|}{ Myanmar } \\
\hline Luxembourg & $\begin{array}{l}\text { Human Resources Development in the Hospitality } \\
\text { and Tourism Sector }\end{array}$ & $2015-2020$ & 6.2 \\
\hline SwissContact, SDC & $\begin{array}{l}\text { Vocational Skills Development Project } \\
\text { (Hotel Training Initiative) }\end{array}$ & $2014-2018$ & 19.6 \\
\hline WCS & $\begin{array}{l}\text { Ayeyarwady Dolphin Protected Area-Community- } \\
\text { Based Ecotourism }\end{array}$ & $2014-2018$ & 0.3 \\
\hline JICA & $\begin{array}{l}\text { Establishment of the Pilot Model for } \\
\text { Regional Tourism Development }\end{array}$ & $2014-2017$ & --- \\
\hline CBI, ITC & Inclusive Tourism Focusing on Kayah State & 2014-2017 & 1.9 \\
\hline $\begin{array}{l}\text { Darwin Initiative, UK } \\
\text { Government }\end{array}$ & $\begin{array}{l}\text { Enhancing Rural Livelihoods and Biodiversity } \\
\text { Conservation through Responsible Tourism, } \\
\text { Myanmar }\end{array}$ & 2014-2017 & --- \\
\hline ICIMOD & Ecotourism Policy and Management Strategy & $2014-2015$ & --- \\
\hline GIZ/CIM, ILO & $\begin{array}{l}\text { Institutional Strengthening of Myanmar Tourism } \\
\text { Federation and Member Organizations }\end{array}$ & 2014-2015 & --- \\
\hline UNDP & $\begin{array}{l}\text { Inle Lake Conservation Five Year Action Plan } \\
(2015-2016 \text { to 2019-2020) }\end{array}$ & $2014-2015$ & --- \\
\hline $\mathrm{ADB}$ & $\begin{array}{l}\text { Promoting Women-Led Micro-Enterprises } \\
\text { in the East-West Economic Corridor }\end{array}$ & $2015-2018$ & 3.0 \\
\hline $\begin{array}{l}\text { ICIMOD and } \\
\text { Luxembourg }\end{array}$ & $\begin{array}{l}\text { Destination Management Plan for the } \\
\text { Inlay Lake Region }\end{array}$ & 2014 & --- \\
\hline Government of Italy & $\begin{array}{l}\text { Implementation of the Tourism Master Plan and } \\
\text { Update of the Tourism Sector Legal and Regulatory } \\
\text { Framework }\end{array}$ & $2013-2014$ & 0.2 \\
\hline MIID, ICIMOD & $\begin{array}{l}\text { Destination Development Plan for the } \\
\text { Inlay Lake Region }\end{array}$ & $2013-2014$ & --- \\
\hline ADB, Norway & Myanmar Tourism Master Plan & 2013 & 0.2 \\
\hline HSF & $\begin{array}{l}\text { Supporting Responsible Tourism Development } \\
\text { in Myanmar }\end{array}$ & 2012- & --- \\
\hline
\end{tabular}


Continued

\begin{tabular}{|c|c|c|c|}
\hline Development Partner & Project/Technical Assistance & Duration & $\begin{array}{l}\text { Cost } \\
\text { Estimate } \\
(\$ \text { million })\end{array}$ \\
\hline \multicolumn{4}{|c|}{ Viet Nam } \\
\hline ADB & $\begin{array}{l}\text { GMS Tourism Infrastructure for Inclusive Growth } \\
\text { Project }\end{array}$ & 2015-2019 & 50.0 \\
\hline European Union & $\begin{array}{l}\text { Environmentally and Socially Responsible Tourism } \\
\text { Capacity Development Programme }\end{array}$ & 2011-2016 & 14.7 \\
\hline Luxembourg & $\begin{array}{l}\text { Strengthening of Human Resources in the } \\
\text { Hospitality and Tourism Sector in Vietnam }\end{array}$ & $2009-2015$ & 4.9 \\
\hline ADB & GMS Sustainable Tourism Development Project & 2008-2014 & 10.0 \\
\hline KfW, GIZ & $\begin{array}{l}\text { Integrated Nature Conservation and Sustainable } \\
\text { Management of Natural Resources in the } \\
\text { Phong Nha Ke Bang National Park Region }\end{array}$ & $2007-2016$ & 12.0 \\
\hline European Union & Human Resources Development in Tourism & 2004-2010 & 15.8 \\
\hline ADB & GMS Mekong Tourism Development Project & $2003-2010$ & 7.9 \\
\hline Luxembourg & Hospitality and Tourism Development Project & $1996-2006$ & 9.0 \\
\hline \multicolumn{4}{|c|}{ Regional Technical Assistance } \\
\hline ADB & GMS Tourism Sector Strategy 2005-2015 & 2005 & 0.9 \\
\hline ADB & $\begin{array}{l}\text { GMS Phnom Penh Plan for Development } \\
\text { Management }\end{array}$ & $2002-2015$ & 13.4 \\
\hline
\end{tabular}

$---=$ data not available; $\mathrm{ADB}=$ Asian Development Bank; ASEAN = Association of Southeast Asian Nations; $\mathrm{CBI}=\mathrm{Center}$ for the Promotion of Imports from Developing Countries (Ministry of Foreign Affairs, Netherlands); CIM = Centre for International Migration and Development; GIZ = Deutsche Gesellschaft für Internationale Zusammenarbeit; GMS = Greater Mekong Subregion; Govt. = Government; HSF = Hanns Seidel Foundation; ICIMOD = International Centre for Integrated Mountain Development; ILO = International Labour Organization; ITC = International Trade Centre; JFPR = Japan Fund for Poverty Reduction; JICA = Japan International Cooperation Agency; Lao PDR = Lao People's Democratic Republic; MIID = Myanmar Institute for Integrated Development; NZAID = New Zealand International Development Agency; SDC = Swiss Agency for Development and Cooperation; SECO = Swiss State Secretariat for Economic Affairs; SNV = Netherlands Development Organization; UK = United Kingdom; UNESCO = United Nations Educational, Scientific and Cultural Organization; UNWTO = United Nations World Tourism Organization; UXO = unexploded ordnance; WCS = Wildlife Conservation Society; WWF = World Wildlife Fund.

Source: ADB estimates. 


\section{Appendix 3 Strategic Linkages}

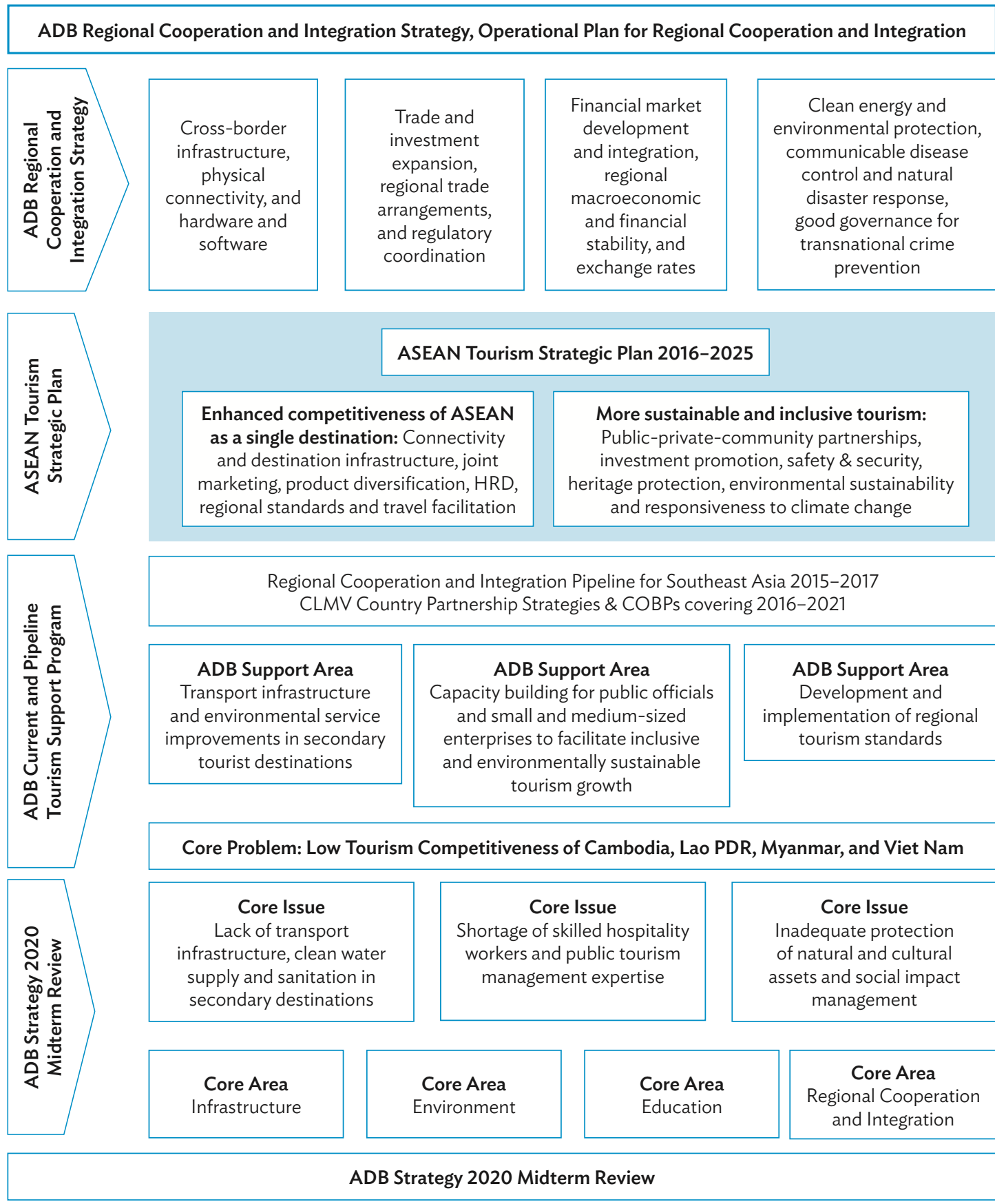

$\mathrm{ADB}=$ Asian Development Bank; ASEAN = Association of Southeast Asian Nations; CLMV = Cambodia, the Lao People's Democratic Republic, Myanmar, and Viet Nam; COBP = country operations business plan; HRD = human resource development; Lao PDR = Lao People’s Democratic Republic.

Source: Asian Development Bank. 


\section{Tourism Sector Assessment, Strategy, and Road Map for Cambodia, Lao People's Democratic Republic, Myanmar, and Viet Nam (2016-2018)}

This report documents tourism sector investment priorities of the Asian Development Bank (ADB) and the governments of Cambodia, the Lao People's Democratic Republic, Myanmar, and Viet Nam. It highlights sector performance, priority development constraints, government plans and strategies, past ADB support and experience, and other development partner support. The report provides sector background information for ADB's investment and technical assistance operations and will be updated as strategic developments and program changes are needed.

\section{About the Asian Development Bank}

ADB's vision is an Asia and Pacific region free of poverty. Its mission is to help its developing member countries reduce poverty and improve the quality of life of their people. Despite the region's many successes, it remains home to a large share of the world's poor. ADB is committed to reducing poverty through inclusive economic growth, environmentally sustainable growth, and regional integration.

Based in Manila, ADB is owned by 67 members, including 48 from the region. Its main instruments for helping its developing member countries are policy dialogue, loans, equity investments, guarantees, grants, and technical assistance. 